SJ Quinney College of Law, University of Utah Utah Law Digital Commons

Utah Law Faculty Scholarship

Utah Law Scholarship

9-2018

\title{
Uniform Conservation Easement Act Study Committee Background Report
}

Nancy McLaughlin

S.J. Quinney College of Law, University of Utah, nancy.mclaughlin@law.utah.edu

Follow this and additional works at: https://dc.law.utah.edu/scholarship

Part of the Property Law and Real Estate Commons

\section{Recommended Citation}

McLaughlin, Nancy, "Uniform Conservation Easement Act Study Committee Background Report" (2018). Utah Law Faculty Scholarship. 119.

https://dc.law.utah.edu/scholarship/119 


\title{
Uniform Conservation Easement Act Study Committee Background Report
}

\author{
June 11, 2017
}

Nancy A. McLaughlin

Robert W. Swenson Professor of Law

University of Utah S.J. Quinney College of Law

383 South University Street

Salt Lake City, Utah 84112

(801) 209-4449

nancy.mclaughlin@law.utah.edu

(C)2017 by Nancy A. McLaughlin, All Rights Reserved. 


\section{Table of Contents}

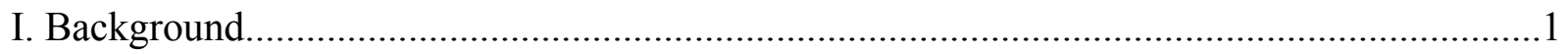

II. The UCEA

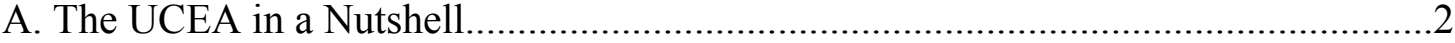

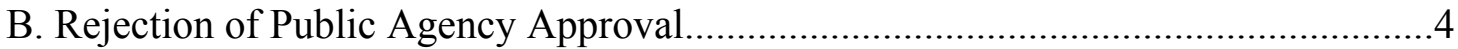

C. Issues Intentionally Not Addressed..................................................................5

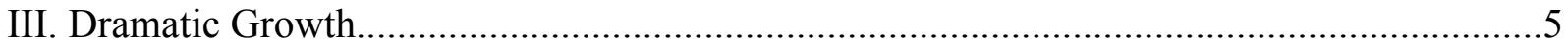

IV. Statutory Commonalities and Differences..............................................................



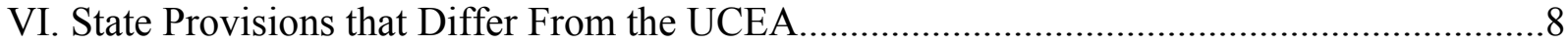

A. Public Review Process at Creation......................................................................

B. Registration or Notice Requirement............................................................... 10

C. Minimum Life for Nonprofit Holders................................................................ 12

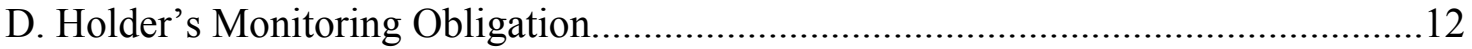

E. Liberal Construction in Favor of Conservation Purposes........................................13

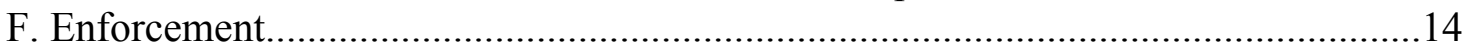

(i) Holder's Right of Entry

(ii) Injunction or Proceeding at Law or in Equity

(iii) Damages

(iv) Connecticut's Encroachment Statute

(v) Restatement (Third) of Property: Servitudes

G. Adverse Possession, Laches, Estoppel, and Waiver...............................................18

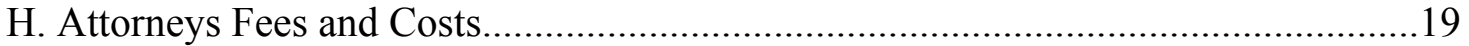

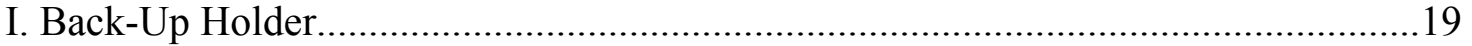

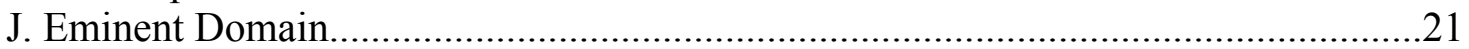

(i) Limited Protections in Enabling Statutes

(ii) Protections in Agricultural Easement Statutes

(iii) Compensation to Holder

(iv) Additions to Eminent Domain Laws

K. Merger, Marketable Title Acts, and Tax Lien Laws.

(i) Broad Provisions

(ii) Merger

(iii) Marketable Title Acts

(iv) Tax Lien Laws

L. Property Tax Assessments. 30

M. Duration, Amendment, and Extinguishment.

(i) The UCEA

(ii) State Enabling Statutes

(iii) Federal Tax Law Requirements 
(a) Internal Revenue Code $\S 170(\mathrm{~h})$

(b) IRS and Senate Finance Committee Concerns

(iv) Restatement (Third) of Property: Servitudes

N. Standing to Sue.

(i) Introduction

(ii) The UCEA

(iii) State Enabling Statutes

O. Holder Immunity from Liability .52

P. Coordination with Permit Processes......................................................................53

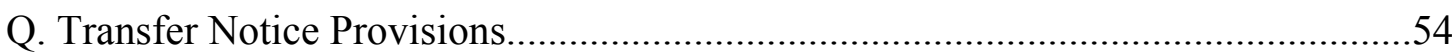

R. Protection of Water Areas or Water Rights..........................................................55 


\section{Background}

Conservation easements are generally held by governmental entities or charitable conservation organizations "in gross." The benefit of the easement runs to the governmental or nonprofit holder and the general public rather than to the owner of some nearby property, as would be the case with a more traditional "appurtenant" easement.

Historically, courts struck down most private land use restrictions held in gross because they were viewed as reducing the marketability of land. Over time, however, state legislators came to recognize that restricting the development and other uses of property for conservation or historic preservation purposes can provide significant benefits to the public. Accordingly, to facilitate the use of conservation easements as land protection and historic preservation tools for the benefit of the public, all fifty states and the District of Columbia enacted some form of legislation that removes the potential common law impediments to the creation and long-term validity of conservation easements. These statutes are generally referred to as conservation easement "enabling" statutes.

In just over half the states and the District of Columbia, the conservation easement enabling statute is based on the Uniform Conservation Easement Act (UCEA), which the National Conference of Commissioners on Uniform State Laws, now known as the Uniform Law Commission (ULC), approved in 1981. ${ }^{1}$ The other states have enacted their own form of enabling statute, in some cases well before the approval of the UCEA. ${ }^{2}$

\footnotetext{
${ }^{1}$ Uniform Conservation Easement Act (last revised or amended in 2007) [hereinafter UCEA]. The ULC reports that twenty-one states, as well as the District of Columbia and the U.S. Virgin Islands have enacted the UCEA. See Uniform Law Commission, Legislative Fact Sheet, http://www.uniformlaws.org/LegislativeFactSheet.aspx?title=Conservation\%20Easement $\% 20$ Act (the listed states are Alabama, Alaska, Arizona, Arkansas, Delaware, Idaho, Indiana, Kansas, Kentucky, Maine, Minnesota, Mississippi, Nevada, New Mexico, Oregon, South Carolina, South Dakota, Texas, Virginia, Wisconsin, and Wyoming). Missouri adopted the UCEA in 2011. Enabling statutes in five additional states also appear to be based on the UCEA (Georgia, Louisiana, Oklahoma, Pennsylvania, and West Virginia).

${ }^{2}$ For example, the Virginia Open Space Land Act, which authorizes the creation of open space easements conveyed to public bodies, was enacted in1966. VA. CODE ANN. $\S$ 10.1-1700 to -1705. The Massachusetts enabling statute was enacted in 1969. MASS. GEN. LAWS ANN. ch. 184, §§ 31-33. Virginia also enacted a version of the UCEA in 1988. VA. CODE ANN. §§ 10.1-1009 to -1016. As of 2010, there were more than one hundred state statutes authorizing the creation or purchase of a wide variety of conservation easements. See McLaughlin, Internal Revenue Code Section 170(h): National Perpetuity Standards for Federally Subsidized Conservation Easements, Part 2: Comparison to State Law, 46 ReAl Prop. Tr. \& Est. L. J. 1, 19, Appendices A and B (2011). Roughly half of these statutes, like the UCEA, can be characterized as "general" enabling statutes, in that they authorize the creation of conservation easements for a fairly broad range of conservation or historic preservation purposes and remove the common law impediments to the long-term validity of such instruments. The variability in the other statutes makes them difficult to characterize. However, the other statutes, for example (i) authorize the acquisition of easements, often by government entities, for very specific purposes, such as the protection of scenic views from highways, drinking water resources, or river shorelands; (ii) establish easement purchase programs, such as programs authorizing government entities to acquire easements protecting productive agricultural lands; or (iii) establish easement grant programs, whereby state funds are provided to government entities or nonprofits to acquire conservation easements. This Report focuses on the general enabling statutes.
} 


\section{The UCEA}

The UCEA was intentionally limited in scope: "The Act has the relatively narrow purpose of sweeping away certain common law impediments which might otherwise undermine the easements' validity, particularly those held in gross." "The intention was to "facilitate[] the enforcement of conservation easements serving the public interest." "To ensure that conservation easements serve the public interest, certain controls were included in the Act, including the requirement that easements be created for purposes intended to benefit the public, and the requirement that easements be conveyed to and held by entities that are organized and operated to serve the public. ${ }^{5}$

\section{A. The UCEA in a Nutshell}

Section 1(1) of the UCEA defines a "conservation easement" broadly as:

a nonpossessory interest of a holder in real property imposing limitations or affirmative obligations the purposes of which include retaining or protecting natural, scenic, or openspace values of real property, assuring its availability for agricultural, forest, recreational, or open-space use, protecting natural resources, maintaining or enhancing air or water quality, or preserving the historical, architectural, archaeological, or cultural aspects of real property.

Section 1(2) limits "holders" to governmental bodies empowered to hold interests in real property and charitable entities, the purposes or powers of which include the purposes for which a conservation easement can be created.

Section 1(3) to authorizes the parties to, in the conservation easement instrument, grant an entity eligible to be a holder a right to enforce the easement (a "third-party right of enforcement").

Section 2(a) provides that, "except as otherwise provided in this Act, a conservation easement may be created, conveyed, recorded, assigned, released, modified, terminated, or otherwise altered or affected in the same manner as other easements."

Section 2(b) provides that "[n]o right or duty in favor of or against a holder and no right in favor of a person having a third-party right of enforcement arises under a conservation easement before its acceptance by the holder and a recordation of the acceptance." This provision was included to address the concern that instruments purporting to impose obligations on a holder might be unilaterally executed by grantors and recorded without notice to or acceptance by the holder.

Section 2(c) provides that, "except as provided in Section 3(b), a conservation easement is unlimited in duration unless the instrument creating it otherwise provides." Section 3(b) provides that the UCEA "does not affect the power of a court to modify or terminate a conservation

\footnotetext{
${ }^{3}$ UCEA, supra note 1, Prefatory Note 2.

${ }^{4}$ Id.

${ }^{5} I d$., Prefatory Note $2, \S 1(1)$ and (2), $\S 2 \mathrm{cmt}$.
} 
easement in accordance with the principles of law and equity." Thus, the default rule under the UCEA is an easement of unlimited duration (i.e., a perpetual easement), subject to the power of a court to modify or terminate the easement in accordance with the principles of law and equity.

Section 2(d) of the UCEA provides that "[a]n interest in real property in existence at the time a conservation easement is created is not impaired by it unless the owner of the interest is a party to the conservation easement or consents to it." This provision acknowledges that an easement cannot impair existing rights unless the owners of those rights join in the easement or consent to it. Thus, easement-encumbered property will be subject to existing liens, encumbrances, and other property rights (such as subsurface mineral rights) that pre-exist the easement unless the owners of those rights either release the rights or subordinate them to the easement.

Section 3(a) addresses standing to bring a judicial action "affecting a conservation easement." It provides that such an action may be brought by (i) the owner of the subject property, (ii) the holder of the easement, (iii) a person having a third-party right of enforcement, or (iv) a person authorized by other law. With regard to "a person authorized by other law," the UCEA comments explain:

the Act also recognizes that the state's other applicable law may create standing in other persons. For example, independently of the Act, the Attorney General could have standing in his capacity as supervisor of charitable trusts, either by statute or at common law. ${ }^{6}$

This is consistent with the drafters' intent to "leave intact" the existing case and statute law of adopting states as it relates to the enforcement of charitable trusts. ${ }^{7}$

Section 4 of the UCEA eliminates (sweeps away) outmoded common law defenses that could impede the use of easements for conservation or preservation ends. It lists such defenses and negates their use in actions to enforce conservation easements.

Section 5(a) provides that the act applies to any interest created after adoption of the act, regardless of how it is denominated (as a conservation easement or as a covenant, equitable servitude, restriction, easement, or otherwise), provided the interest complies with the terms of the act. Labels are irrelevant, but compliance with the UCEA, including the easement purpose, qualified holder, acceptance, and recordation requirements, is necessary.

Recognizing that conservation easements were created before the adoption of the UCEA, Section 5(b) provides that the act applies to any interest created before the act's adoption if the interest would have been enforceable had it been created after the act's adoption, unless retroactive application would contravene the constitution or laws of the adopting state or the United States. The drafters recognized that constitutional difficulties could arise if the UCEA sought to validate interests that were invalid under pre-act statutory or case law.

\footnotetext{
${ }^{6}$ UCEA, supra note $1, \S 3 \mathrm{cmt}$.

${ }^{7}$ Id. Prefatory Note $3, \S 3 \mathrm{cmt}$.
} 
Section 5(c) provides that the UCEA does not invalidate any interest that is enforceable under other laws of the adopting state. Accordingly, interests that are valid under an adopting state's case law or other statutory law are unaffected by the UCEA.

Section 6 sets forth the ULC's standard statement regarding uniformity of application and construction.

\section{B. Rejection of Public Agency Approval}

The UCEA drafters considered and rejected the idea of requiring public agency approval of conservation easements upon their creation, citing "both practical and philosophical reasons." Those reasons were:

(i) the Act has the relatively narrow purpose of sweeping away certain common law impediments that might otherwise undermine the validity of conservation easements;

(ii) the requirement of public agency approval would add a layer of complexity that might discourage easement conveyances because organizations and property owners might be reluctant to become involved in the bureaucratic, and sometimes political, process that public agency approval entails;

(iii) such a requirement might dissuade a state from enacting the UCEA because of the administrative and fiscal burdens associated with operating the approval program;

(iv) controls in the UCEA help to ensure that the UCEA will serve the public interest, including the requirement that holders of conservation easements be limited to governmental agencies and charitable organizations, neither of which is likely to accept easements on an indiscriminate basis;

(v) controls in other state and federal legislation afford further assurance that the UCEA will serve the public interest, for example, federal tax statutes and regulations "rigorously define the circumstances under which easement donations qualify for favorable tax treatment";

(vi) controls relating to real estate assessment and taxation of restricted properties have been, or can be, imposed by state legislatures to prevent easement abuses or to limit potential loss of local property tax revenues resulting from unduly favorable assessment and taxation of encumbered properties; and

(vii) the American legal system generally regards private ordering of property relationships as sound public policy. ${ }^{9}$

${ }^{8} I d$., Prefatory Note 2.

${ }^{9} \mathrm{Id}$. 


\section{Issues Intentionally Not Addressed}

The UCEA drafters specifically declined to address a number of issues which, though of conceded importance, were considered extraneous to the act's primary objective of sweeping away certain common law impediments that might otherwise undermine the easements' validity. ${ }^{10}$ The issues not addressed include the following.

(i) Formalities and Effects of Recordation. With the exception of the requirement that the holder's acceptance of an easement must be recorded, ${ }^{11}$ the formalities and effects of recordation are left to an adopting state's registry system. The drafters noted that an adopting state may wish to establish special indices for conservation easements, as provided for in the Massachusetts enabling statute.

(ii) Marketable Title Act. The potential impact of a state's marketable title laws upon the duration of conservation easements was not addressed. The drafters stated that the adopting state should consider the relationship between UCEA $\S 2(\mathrm{c})$, which provides that easements have an unlimited duration unless the instruments creating them provide otherwise, and the state's marketable title act or other statutes addressing restrictions on real property of unlimited duration.

(iii) Local Property Tax Assessment and Taxation. The relationship between the UCEA and local real property assessment and taxation practices was not addressed. For example, the effect of an easement on the valuation of the burdened real property was left to the state and local taxation system.

(iv) Eminent Domain. The UCEA neither limits nor enlarges the power of eminent domain. Such matters as the scope of the eminent domain power and the entitlement of property owners to compensation upon its exercise are determined, not by the UCEA, but by the adopting state's eminent domain code and related statutes.

\section{Dramatic Growth}

The growth in the use of conservation easements since the approval of the UCEA in 1981 has been dramatic. The public has invested and continues to invest billions in conservation easements through a variety of federal, state, and local tax incentive and easement purchase programs. Although there are no complete sources of data, the National Conservation Easement Database (NCED) estimates that 40 million acres are now encumbered by conservation easements

${ }^{10} I d$., Prefatory Note 3 .

${ }^{11}$ Id., $\S 2$ (b). 
in the United States. ${ }^{12}$ The graph below from the NCED illustrates that much of the growth in the use of easements has occurred over the last three decades. ${ }^{13}$

\section{Easements by Acquisition Date}

This graph may not represent the total acreages for all conservation easements in the region due to missing data.

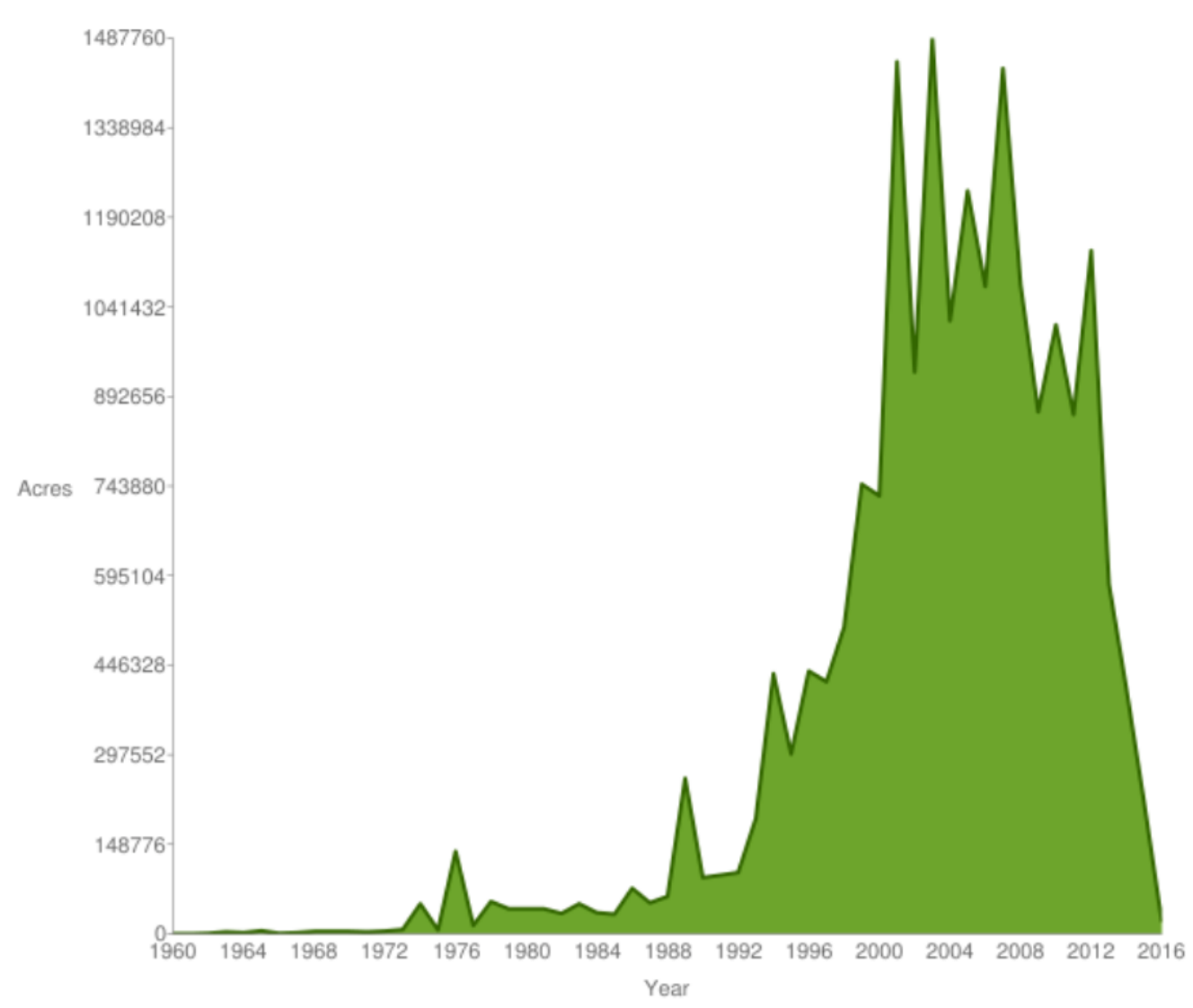

IV. Statutory Commonalities and Differences

The conservation easement enabling statutes that have been enacted in the fifty states and the District of Columbia generally share a number of common characteristics. Like the UCEA, they generally (i) sweep away the common law impediments to the creation and long-term validity of conservation easements; (ii) mandate that conservation easements be created for specified

\footnotetext{
${ }^{12}$ National Conservation Easement Database, What is the NCED?, at http://conservationeasement.us (last visited June 2 , 2017). The NCED includes data on conservation easements held by charitable organizations, government entities (federal, state, and local), and tribes, among others. Because the NCED is still in the process of gathering data, and participating in the NCED is voluntary on the part of easement holders and property owners, the database is not complete. See id., Completeness, at http://conservationeasement.us/about/completeness (last visited June 2, 2017).

${ }^{13}$ See id., All States and All Easements, at http://conservationeasement.us/reports/easements (last visited June 2, 2017).
} 
conservation or historic preservation purposes intended to benefit the public; ${ }^{14}$ and (iii) mandate that conservation easements be conveyed to and held by entities that are organized and operated to serve the public - i.e., governmental entities or charitable organizations. ${ }^{15}$ In addition, most of the statues enable the parties to create easements with a variety of durations, with the default being easements of unlimited duration (i.e., perpetual easements). ${ }^{16}$

However, some of the enabling statutes contain provisions that differ from those found in the UCEA. In addition, over the past several decades, numerous states have amended their enabling statutes or added provisions to their other laws that affect conservation easements.

\section{Study Committee Considerations}

The Study Committee has been tasked with exploring whether there is a need for, and, if so, the appropriate scope and breadth of, potential amendments to the UCEA. The Committee is also tasked with exploring the extent to which suitable non-uniform enabling acts exist in jurisdictions that have not enacted the UCEA, and whether amendments to the UCEA could or would prove useful in an effort to expand the UCEA's enactment footprint, as compared to the UCEA in its current form.

In considering these issues, the Study Committee may wish to take into account the interests of the various stakeholders in this context. Stakeholders include:

(i) the individuals who convey conservation easements, often to ensure that specific properties that have special meaning to them, their families, and their communities will be protected from development and other environmentally harmful uses in perpetuity;

(ii) individual, institutional, and governmental funders who contribute to specific conservation easement acquisition projects;

(iii) federal and state taxpayers, who are investing billions of dollars in conservation easements through federal and state tax-incentive and easement-purchase programs;

(iv) the charitable and local, state and federal government entities that acquire and administer easements on behalf of the public;

(v) owners of easement-encumbered properties, whether the easement grantors or subsequent owners, who must comply with the restrictions on the use of the properties;

\footnotetext{
${ }^{14}$ The precise recitation of the purposes for which an easement can be created can vary. For example, Hawaii includes traditional and family cemeteries, South Dakota and Alabama include paleontological resources, and New York includes old-growth forest. See HAW. Rev. StaT. AnN. § 198-1(3); S.D. Codified LAWS § 1-19B-56(1); Ala. CodE $\S 35-18-1(1)$; N.Y. ENVTL. CONSERV. §§ 49-0301 and 49-0303.1.

${ }^{15}$ Only two states include private individuals or private entities as eligible holders. N.C. GEN. STAT. ANN. § 121-35(2) (a private corporation or business entity whose purposes include the purposes for which conservation easements in the state can be created is an eligible holder); Mo. ANN. STAT. § 442.014.2(2)(c) (an individual or other private entity is an eligible holder).

${ }^{16}$ See infra Part VI.M.(ii).
} 
(vi) community members, who both invest in and benefit from the often perpetual protection of land within their communities;

(vii) the IRS and the Treasury Department, which oversee and enforce the federal tax incentive program that has been the major driver of the growth in the use conservation easements; and

(viii) state attorneys general and other public officials who are charged with overseeing charities and protecting the public interest in assets held for the benefit of the public within their jurisdictions.

Consideration might also be given to (i) whether any proposed change to the UCEA would have to apply prospectively only due to constitutional or other limits on retroactive application, ${ }^{17}$ and (ii) the impact any change may have on the ability of easement grantors or grantees in an adopting state to qualify for federal, state, or local tax incentives or other subsidies.

\section{State Provisions that Differ from the UCEA}

The following subparts review provisions included in state enabling statutes or other parts of state codes that differ from the UCEA. The following is not intended to be an exhaustive discussion of these provisions. Rather, it is intended only to bring the provisions to the attention of the Study Committee.

\section{A. Public Review Process at Creation}

As noted in Part II.B above, the UCEA drafters specifically considered and rejected the idea of requiring public agency approval of conservation easements. The enabling statutes in six states provide for some form of direct or indirect public review or approval of conservation easements.

The Massachusetts's statute, which was enacted in 1969 and considered by the UCEA drafters, requires that conservation easements be approved by designated public officials, and easements held by charitable entities are subject to two layers of approval. ${ }^{18}$ In determining whether an easement is in the public interest, a public official must take into consideration the public interest in such preservation; any national, state, regional, and local program in furtherance of such preservation; any public state, regional, or local comprehensive land use or development plan affecting the land; and any known proposal by a governmental body for use of the land. In addition, the Massachusetts Executive Office of Environmental Affairs has published easement

\footnotetext{
${ }^{17}$ See, e.g., Windham Land Trust v. Jeffords, 967 A.2d 690 (Me. 2009) (statutory provision addressing attorney general standing applied retroactively because it was not fundamentally unfair, nor did it violate the Contract Clauses of the Maine or United States Constitutions); McLaughlin \& Weeks, In Defense of Conservation Easements: A Response to The End of Perpetuity, 9 WYO. L. REV. 1, 87-91 (2009) (explaining that attempts by state legislatures to terminate or otherwise weaken or undermine existing conservation easements could be vulnerable to challenge on constitutional grounds).

${ }^{18}$ MASS. GEN. LAWS ANN. ch. 184, § 32. Massachusetts refers to conservation easements as conservation restrictions.
} 
guidelines, criteria, and forms that must be used in the absence of a demonstrated reason otherwise. $^{19}$

To minimize conflicts with land-use planning, Nebraska's statute requires that the state give the local planning commission an opportunity to comment on the state's acquisition of an easement, but approval by the local planning commission is not required. ${ }^{20}$ Other conservation easements must be approved by the appropriate governing body after receiving comments from the local planning commission. Approval of a proposed acquisition may be denied upon a finding that the acquisition is inconsistent with (i) the comprehensive plan for the area, (ii) any national, state, regional, or local program furthering conservation or preservation, or (iii) any known proposal by a governmental body for use of the land. One commentator has reported that most easements in Nebraska are approved. ${ }^{21}$

To minimize conflict with local comprehensive planning, Montana's statute requires that all conservation easements be reviewed by the appropriate local planning authority before recordation. ${ }^{22}$ The entity acquiring the conservation easement is required to present the proposed conveyance to the local planning authority, and the local planning authority is givens 90 days to review and to comment upon the relationship of the proposed conveyance to comprehensive planning for the area. The local planning authority's comments are expressly not binding and merely advisory in nature.

Oregon's statute requires that state agencies and other state governmental entities hold one or more public hearings before acquiring conservation easements. ${ }^{23}$ The hearings must be held in the community where the easement would be located and all interested persons must be given the right to appear and a reasonable opportunity to be heard.

Virginia's two enabling statutes require that conservation easements conform to the comprehensive plan for the area in which the subject property is located. ${ }^{24}$ It can sometimes be unclear whether a proposed easement would be consistent with the applicable comprehensive plan.

One of Washington's two enabling statutes provides that a county acquiring conservation easements with property tax revenues must determine if the easements would reduce the capacity of land suitable for development necessary to accommodate the allocated housing and employment growth, as adopted in the countywide planning policies. ${ }^{25}$ When actions are taken that reduce

\footnotetext{
${ }^{19}$ See Div. of Conservation Serv., Office Of Energy \& Envtl. Affairs, Commw. Of Mass., The MassachuSETtS CONSERVATION RESTRICTION HANDBOOK (1991), available at http://atfiles.org/files/pdf/MAconsrestrict08.pdf; Pidot, Reinventing Conservation Easements: A Critical Examination and Ideas for Reform 11 (Lincoln Institute of Land Policy 2005).

${ }^{20}$ NeB. ReV. STAT. § 76-2,112(3) and (4).

${ }^{21}$ See Levin, A Guided Tour of the Conservation Easement Enabling Statutes 14 (Land Trust Alliance 2014).

${ }^{22}$ Mont. CoDE ANN. § 76-6-206.

${ }^{23}$ OR. REV. STAT. § 271.735.

${ }^{24}$ VA. CODE ANN. § 10.1-1010(E) ("No conservation easement shall be valid and enforceable unless the limitations or obligations created thereby conform in all respects to the comprehensive plan at the time the easement is granted for the area in which the real property is located."); VA. CODE ANN. § 10.1-1701 ("[t]he use of the real property for open-space land shall conform to the official comprehensive plan for the area in which the property is located.").

${ }^{25}$ WASH. REv. CODE ANN. $\S \S 84.34 .230 ; 84.34 .240(3)$. The Washington statute refers to conservation easements as “conservation futures." See also WASH. REV. CODE ANN. § 64.04.130.
} 
capacity to accommodate planned growth, the jurisdiction must adopt reasonable measures to increase the capacity lost by such actions.

\section{B. Registration or Notice Requirement}

A number of enabling statutes require that easements be registered with or sent to certain government agencies or officials.

The Illinois statute requires the recorder or the Registrar of Titles to, upon recordation, cause a copy of the conservation easement to be mailed to the Department of Natural Resources. ${ }^{26}$

Iowa's statute requires each public body acquiring one or more conservation easements to maintain a current inventory thereof. ${ }^{27}$ Unrecorded and uninventoried conservation easements are deemed abandoned.

Maine's statute requires any holder of a conservation easement that is organized or doing business in the state to annually report to the Department of Agriculture, Conservation and Forestry (DACF) the book and page number at the registry of deeds for each conservation easement that it holds, the municipality and approximate number of acres protected under each easement, and such other information as DACF determines necessary. ${ }^{28}$ The annual filing must be accompanied by a $\$ 30$ fee. DACF is required report to the Attorney General any failure of a holder disclosed by the filing or otherwise known to DACF. There are differing interpretations of what constitutes a reportable "failure" of a holder.

The Massachusetts statute authorizes cities and towns to create a map or set of maps depicting conservation easements and relevant information about such easements, known as "public restriction tract indexes." 29 The statute directs that the maps be in a form that can be readily added to, changed, and reproduced, and that they constitute public records appropriately available for public inspection. The registers of deeds are authorized to make and amend rules and regulations for the administration of the indexes, although no such rule, regulation, or amendment can take effect until after it has been approved by the attorney general. Cities and towns are not required to create these indexes and apparently few have done so.

Mississippi's statute requires the clerk of the court recording an easement to mail certified copies thereof, together with notice as to the date and place of recordation, to the Mississippi Attorney General and the Mississippi Department of Wildlife, Fisheries and Parks. ${ }^{30}$ This requirement must be stated in the easement instrument.

Montana's statute requires the county clerk and recorder to provide a copy of every conservation easement to the department of revenue office in the county within 30 days of the

\footnotetext{
26765 Ill. COMP. STAT. ANN. 120/5.

${ }^{27}$ IOWA CODE ANN. § 457A.3.

${ }^{28}$ ME. REV. StAT. ANN. tit. 33, § 479-C.

${ }^{29}$ MASS. GEN. LAWS ANN. ch. 184, § 33.

${ }^{30}$ Miss. CodE ANN. § 89-19-15.
} 
receipt of the easement. ${ }^{31}$ Entities holding easements in Montana before October 2007 were required to provide a copy of all such easements to the department of revenue within six months of October $2007 .{ }^{32}$ The department of revenue is required to transfer all information gathered on the easements to the state library. The library is directed to convert the information into a digital format that can be accessed through its website for purposes of disseminating the information to all interested parties, public and private. ${ }^{33}$

New York's statute requires any person who records an easement to forthwith forward a copy the Department of Environmental Conservation, and the Department is required to maintain a file of conservation easements. ${ }^{34}$ At least thirty days prior to the state's acquisition (or entry into a contract for the acquisition) of an easement, written notice must be provided to the Director of the Budget and published in the state register and the environmental notice bulletin. ${ }^{35}$

Ohio's statute requires the county recorder, promptly after the recording and indexing of an agricultural easement, to mail a photocopy of the instrument to the office of farmland preservation in the department of agriculture. The photocopy must be accompanied by an invoice for the applicable fee. Promptly after receiving the photocopy and invoice, the office of farmland preservation must remit the fee to the county recorder. ${ }^{36}$

Utah's statute requires the owner of property subject to an easement to deliver a copy of the easement and proof of its recordation to the assessor of the county in which the property is located within 10 days of recordation. ${ }^{37}$ Owners of property subject to an easement recorded before May 10, 2011, were required to deliver a copy of the easement and proof of its recordation to the appropriate assessor before January 1, 2012.

Virginia's version of the UCEA requires the party responsible for recording an easement or his agent to mail certified copies thereof, together with any attached plats and a notice specifying the date and place of recordation, to the commissioner of revenue for the local jurisdiction in which the subject property is located, the Director of the Department of Conservation and Recreation, the Virginia Outdoors Foundation, and any other public body named in the instrument. ${ }^{38}$ If a conservation easement is on lands that are part of or contain a historic place or landmark listed on either the National Register of Historic Places or the Virginia Landmarks Register, notice must also be given to the Director of the Department of Historic Resources.

California, in a different part of its Code, requires the county recorder in each county to develop and maintain, within the existing indexing system, a comprehensive index of conservation easements on land within the county. ${ }^{39}$ The index must include all conservation easements recorded on and after January 1, 2002. Any parties to conservation easements recorded prior to

${ }^{31}$ Mont. CodE ANN. § 76-6-207(2)(b).

${ }^{32} I d . \S 76-6-212$.

${ }^{33}$ Id. See also id. $\$ 90-1-402$.

${ }^{34}$ N.Y. ENVTL. CONSERV. § 49-0305.4.

${ }^{35} I d . \S 49-0305.9$.

${ }^{36}$ OHIO REV. CODE ANN. $\$ 5301.691(\mathrm{H})$ (this section of Ohio's statute governs the purchase of agricultural easements).

${ }^{37}$ UTAH CODE ANN. § 57-18-4(2).

${ }^{38}$ VA. CODE ANN. § 10.1-1012.

${ }^{39}$ CAL. Gov. CODE $§ 27255$. 
2002 may fill out and record a Notice of Conservation Easement for such easements. The standard fee charged by a county recorder for recording an easement must include funds to cover the costs associated with indexing the easement.

\section{Minimum Life for Nonprofit Holders}

Two enabling statutes require that a nonprofit operate for a certain number of years before accepting a conservation easement.

Colorado's statute provides:

A conservation easement in gross may only be created through...a grant to or a reservation by a charitable organization exempt under section 501(c)(3) of the federal "Internal Revenue Code of 1986", as amended, which organization was created at least two years prior to receipt of the conservation easement. ${ }^{40}$

Virginia's version of the UCEA provides:

For all easements, the holder shall...either have had a principal office in the Commonwealth for at least five years, or be a national organization in existence for at least five years which has an office in the Commonwealth and has registered and is in good standing with the State Corporation Commission. Until a holder has met these requirements, the holder may co-hold a conservation easement with another holder that meets the requirements. ${ }^{41}$

No enabling statute requires that a holder have a minimum amount of financial resources before accepting a conservation easement. The Illinois statute provides that a holder's acceptance of an easement "may be conditioned upon any requirements which are deemed proper by the grantee" and "[s]uch requirements may include the payment of funds by the grantor to provide for the management of such conservation rights."

\section{Holder's Monitoring Obligation}

Maine's enabling statute mandates that "[t]he holder of a conservation easement shall monitor the condition of the real property subject to the conservation easement at least every 3 years and shall prepare and retain a written monitoring report in its permanent records." 43 The holder must also make a copy of the monitoring report available to the landowner upon request. Failure to comply with the monitoring requirement does not invalidate a conservation easement otherwise entitled to the protections of the statute. ${ }^{44}$ There is no sanction for failure to comply with the monitoring requirement. ${ }^{45}$

\footnotetext{
${ }^{40}$ COLO. REV. STAT. $\$ 38-30.5-104(2)$.

${ }^{41}$ VA. CODE ANN. $§ 10.1-1010(\mathrm{C})$.

42765 Ill. COMP. StAT. ANN. 120/2.

${ }^{43}$ Me. ReV. STAT. ANN. tit. 33, § 477-A.3.

${ }^{44} I d$., $\S 477-\mathrm{A} .4$.

${ }^{45}$ See Pidot, Conservation Easement Reform: As Maine Goes Should the Nation Follow?, 74 DUKE J. L. \& CONTEMP. PROBS 1, 22 (2011) (“The omission of monetary penalties was intentional because the Reform Law's purpose was to establish clear standards that holders would find it in their interests to follow, especially to maintain good standing
} 


\section{Ohio's enabling statute provides:}

With respect to an agricultural easement purchased with a matching grant...that consists in whole or in part of moneys from the clean Ohio agricultural easement fund..., the recipient of the matching grant shall make an annual monitoring visit to the land that is the subject of the easement. The purpose of the visit is to ensure that no development that is prohibited by the terms of the easement has occurred or is occurring...the grant recipient shall prepare a written annual monitoring report and submit it to the office of farmland preservation in the department of agriculture. If necessary to enforce the terms of the easement, the grant recipient shall take corrective action in accordance with those rules. The director [of agriculture] may agree to share these monitoring and enforcement responsibilities with the grant recipient. ${ }^{46}$

\section{E. Liberal Construction in Favor of Conservation Purposes}

Two enabling statutes (Pennsylvania and West Virginia) mandate that conservation easements be liberally construed in favor of effecting their conservation purposes and the policy and purpose of the enabling statute. Both statutes also contain a "purpose" clause emphasizing the public benefits provided by conservation easements.

Pennsylvania's statute provides:

The General Assembly recognizes the importance and significant public and economic benefit of conservation and preservation easements in its ongoing efforts to protect, conserve or manage the use of the natural, historic, agricultural, open space and scenic resources of this Commonwealth. ${ }^{47}$

Any general rule of construction to the contrary notwithstanding, conservation or preservation easements shall be liberally construed in favor of the grants contained therein to effect the purposes of those easements and the policy and purpose of this act. ${ }^{48}$

West Virginia's statute provides:

The West Virginia Legislature recognizes the importance and significant public benefit of conservation and preservation easements in its ongoing efforts to protect the natural, historic, agricultural, open-space and scenic resources of this state. ${ }^{49}$

with donors and supporters. As these legal expectations have now become well understood and respected, appropriate monetary sanctions might be considered in the future for targeted types of violations.").

${ }^{46}$ OHIO REV. CODE ANN. § 5301.691(E)(2) (this section of Ohio's statute governs the purchase of agricultural easements).

4732 PA. CONS. STAT. $\$ 5052$.

${ }^{48} I d . \S 5055(\mathrm{c})(2)$.

${ }^{49}$ W. VA. CODE $\S 20-12-2$. 
Notwithstanding provision of law to the contrary, conservation and preservation easements shall be liberally construed in favor of the grants contained therein to effect the purposes of those easements and the policy and purpose of this article. ${ }^{50}$

Conservation easement instruments are increasingly drafted to include a liberal construction provision similar to the statutory provisions noted above. In the absence of such a provision in the instrument or in the enabling statute, there is a danger that ambiguous terms in an easement will be construed in favor of the free use of land. In Wetlands America Trust v. White Cloud Nine Ventures ${ }^{51}$ the Virginia Supreme Court held that the common law rule of construction requiring land use restrictions to be interpreted in favor of free use of land applied to the conservation easement at issue, which did not contain a liberal construction provision. The court also held that the neither of the two enabling statutes in Virginia abrogated the common law rule of construction in favor of free use of land.

The Virginia Attorney General filed an amicus brief in Wetlands America Trust. ${ }^{52}$ He did not take a position regarding the substance of the dispute (i.e., whether certain of the landowner's activities on the subject property violated the easement). However, he argued that conservation easements are distinguishable from traditional restrictive covenants because of the strong public policy in favor of and the considerable public investment in such easements and, thus, they should not be interpreted using the "free use of land" rule. While the Attorney General failed to persuade a majority of the Virginia Supreme Court, there was a strong dissent in the case.

\section{F. Enforcement}

\section{(i) Holder's Right of Entry}

A number of the enabling statutes address the right of the holder to enter the encumbered property for enforcement purposes. The following are examples.

\footnotetext{
${ }^{50} I d$. $\$ 20-12-5(\mathrm{~b})$. California's enabling statute provides that "The Legislature finds and declares that the preservation of land in its natural, scenic, agricultural, historical, forested, or open-space condition is among the most important environmental assets of California. The Legislature further finds and declares it to be the public policy and in the public interest of this state to encourage the voluntary conveyance of conservation easements to qualified nonprofit organizations." CAL. CIV. CODE $\S 815$. The statute further provides "The provisions of this chapter shall be liberally construed in order to effectuate the policy and purpose of Section 815." Id. $\S 816$. The statute also provides, however, that "All interests not transferred and conveyed by the instrument creating the easement shall remain in the grantor of the easement, including the right to engage in all uses of the land not affected by the easement nor prohibited by the easement or by law," which could undermine $\S 816$ 's liberal construction provision. Id. $\S 815.4$. Rhode Island's enabling statute has a purpose clause that provides: "The purpose of this chapter is to grant a special legal status to conservation restrictions and preservation restrictions so that landowners wishing to protect and preserve real property may do so without uncertainty as to the legal effect and enforceability of those restrictions. This chapter is further intended to provide the people of Rhode Island with the continued diversity of history and landscape that is unique to this state without great expenditures of public funds." R.I. GEN. LAWS § 34-39-1.

${ }^{51}$ Wetlands America Trust v. White Cloud Nine Ventures, 782 S.E.2d 131 (Va. 2016).

${ }^{52}$ Wetlands America Trust v. White Cloud Nine Ventures, Brief of the Commonwealth of Virginia Amicus Curiae in Support of Appellant (on file with author). See also McLaughlin, Interpreting Conservation Easements, 29 PROB. \& PROP. 30 (2015).
} 
Arkansas: "Conservation easements may be enforced by injunction or other proceeding in equity and shall entitle representatives of the holder to enter the land in a reasonable manner and at reasonable times to assure compliance. ${ }^{, 53}$

Tennessee: "The holder of a conservation easement shall maintain the right of entry at reasonable times for inspection whether or not the easement specifically permits such rights of entry.",54

New York: "The holder of a conservation easement, its agents, employees, or other representatives may enter and inspect the property burdened by a conservation easement in a reasonable manner and at reasonable times to assure compliance with the restriction." ${ }^{55}$

Maine: "The instrument creating a conservation easement must provide in what manner and at what times representatives of the holder of a conservation easement or of any person having a 3rd-party right of enforcement shall be entitled to enter the land to assure compliance. ${ }^{56}$

Maine's statute refers to a right of entry of both the holder and a third party with a right of enforcement. The Tennessee and New York statutes reference both entry and inspection, and provide a right of entry regardless of whether such right is set forth in the easement instrument.

\section{(ii) Injunction or Proceeding at Law or in Equity}

Just over one-third of the enabling statutes provide that a court may enforce a conservation easement by injunction or in a proceeding at law or in equity. The following are examples. Arkansas: "Conservation easements may be enforced by injunction or other proceeding in

Illinois: "A conservation right created pursuant to this Act may be enforced in an action seeking injunctive relief, specific performance, or damages in the circuit court of the county in which the area, place, building, structure or site is located...."

New York: "A conservation easement may be enforced in law or equity by its grantor, its holder or by a public body or any not-for-profit conservation organization designated in the easement as having a third party enforcement right, and is enforceable against the owner of the burdened property. 59

\footnotetext{
${ }^{53}$ ARK. CODE ANN. § 15-20-409(c).

${ }_{55}^{54}$ TenN. Code ANN. $\$ 66-9-304(\mathrm{c})$.

${ }_{56}^{55}$ N.Y. ENVTL. CONSERV. $\$ 49-0305.6$.

${ }^{56}$ Me. ReV. STAT. ANN. tit. 33, § 477.5.

${ }^{57}$ ARK. CODE ANN. § 15-20-409(c).

${ }^{58} 765$ ILl. COMP. STAT. ANN. 120/4.

${ }^{59}$ N.Y. ENVTL. CONSERV. § 49-0305.5.
} 
Rhode Island: "A restriction may be enforced by an action at law or by injunction or other proceeding in equity." 60

Tennessee: "Conservation easements may be enforced by injunction, proceedings in equity, or actions at law."

Maine: "The court...may enforce a conservation easement by injunction or proceeding at law and in equity. A court may deny equitable enforcement of a conservation easement only when it finds that change of circumstances has rendered that easement no longer in the public interest or no longer serving the publicly beneficial conservation purposes identified in the conservation easement. If the court so finds, the court may allow damages as the only remedy in an action to enforce the easement.

No comparative economic test may be used to determine under this subchapter if a conservation easement is in the public interest or serves a publicly beneficial conservation purpose. ${ }^{, 62}$

\section{(iii) Damages}

A number of enabling statutes (in addition to some of those noted in the previous subpart) provide for damage awards for violation of an easement. The following are examples.

Utah: "In addition to injunctive relief, the holder of a conservation easement is entitled to recover money damages." ${ }^{, 63}$

North Carolina: "Conservation or preservation agreements may be enforced by the holder by injunction and other appropriate equitable relief administered or afforded by the courts of this State. Where appropriate under the agreement, damages, or other monetary relief may also be awarded either to the holder or creator of the agreement or either of their successors for breach of any obligations undertaken by either." ${ }^{44}$

The Illinois statute provides for punitive damages:

Any owner of property subject to a conservation right who willfully violates any term of such conservation right may, in the court's discretion, be held liable for punitive damages in an amount equal to the value of the real property subject thereto. ${ }^{65}$

California's statute expansively provides:

\footnotetext{
${ }^{60}$ R.I. GEN. LAWS $§ 34-39-4$.

${ }^{61}$ TENN. CODE ANN. $§ 66-9-307(\mathrm{c})$.

${ }^{62}$ Me. REV. StAT. AnN. tit. 33, § 478.3 and flush language.

${ }^{63}$ UTAH CODE ANN. § 57-18-6(2).

${ }^{64}$ N.C. GEN. STAT. $§ 121-39$ (a).

65765 Ill. COMP. STAT. ANN. 120/4(c).
} 
In addition to the remedy of injunctive relief, the holder of a conservation easement shall be entitled to recover money damages for any injury to such easement or to the interest being protected thereby or for the violation of the terms of such easement. In assessing such damages there may be taken into account, in addition to the cost of restoration and other usual rules of the law of damages, the loss of scenic, aesthetic, or environmental value to the real property subject to the easement. ${ }^{66}$

The Colorado and Hawaii statutes include a damage provision similar to that in California's statute. $^{67}$

\section{(iv) Connecticut's Encroachment Statute}

Connecticut has a particularly progressive statute addressing "encroachments" on "open space lands," including lands protected by conservation easements. ${ }^{68}$ The statute provides that the owner of easement-encumbered land, the holder of the easement, and the state attorney general can bring an action against any person who "encroaches" upon the land (i.e., who, without permission or legal authorization, causes damage or alteration to the land or vegetation or other features thereon, by, for example, erecting buildings or other structures; constructing roads or driveways; cutting trees or other vegetation; or storing or depositing vehicles, materials, or debris).

The statute authorizes a court to order restoration of the land, award the costs of restoration to the landowner, award reasonable attorney's fees and costs, and award such injunctive or equitable relief as the court deems appropriate. The court may also award damages of up to five times the cost of restoration or statutory damages of up to five thousand dollars. In determining the amount of the award, the statute instructs the court to consider the willfulness of the violation; the extent of damage done to natural resources, if any; the appraised value of any trees or shrubs cut, damaged, or carried away; any economic gain realized by the violator; and any other relevant factors. ${ }^{69}$

\section{(v) Restatement (Third) of Property: Servitudes}

Section 8.5 of the Restatement (Third) of Property: Servitudes (2000) provides a protective rule regarding the enforcement of conservation servitudes:

A conservation servitude held by a governmental body or a conservation organization is enforceable by coercive remedies and other relief designed to give full effect to the purpose of the servitude.

The comments to this section explain, in part:

\footnotetext{
${ }^{66}$ CAL. CIV. CODE $\S 815.7(\mathrm{c})$.

${ }^{67}$ Colo. Rev. Stat. § 38-30.5-108(3); Haw. Rev. Stat. AnN. § 198-(d).

${ }^{68}$ CONN. GEN. STAT. ANN. $§ 52-560$ a. For a recent case involving enforcement of a conservation easement by its holder and the state attorney general, as well as application of Connecticut's encroachment statute, see Lyme Land Conservation Trust v. Platner, _A.3d_, 2017 WL 2123636 (Conn. 2017).

${ }^{69}$ The appraised value must be determined in accordance with the latest revision of THE GUIDE FOR PLANT APPRAISAL, as published by the International Society of Arboriculture, Urbana, Illinois, or a succeeding publisher. CONN. GEN. STAT. ANN. § 52-560a(d).
} 
There is a strong public interest in conservation servitudes. Statutes have been enacted to eliminate questions about their enforceability in all but three states; they are often purchased with public funds or money raised from the public; they are often subsidized with tax benefits and other governmental benefits. The resources protected by conservation servitudes provide important public benefits, but are often fragile and vulnerable to degradation or loss by actions of the holder of the servient estate. Until a conservation servitude is terminated in accordance with rules stated in Chapter 7, it should be vigorously protected by the full panoply of remedies available to protect property interests. Conservation servitudes are not subject to judicial modification to permit development prohibited by the servitude under the rule stated in $\S 7.11$, and, under the rule stated in this section, a judgment for damages may not be substituted for coercive relief.

Conservation servitudes often present a combination of restrictive covenants with easements and affirmative covenants, and appropriate coercive remedies will often include both prohibitory and mandatory injunctions. To give full effect to the purposes of the servitude, it may be necessary to order maintenance and restoration of the protected property to the condition contemplated by the servitude. In appropriate cases, additional remedies may be needed to compensate the public for irreplaceable losses in the value of the property protected by the servitude and other damages flowing from violation of the servitude. Remedies should also be designed to deter servient owners from conduct that threatens the interests protected by the servitude. In addition to punitive damages, which may be awarded in appropriate cases, remedies may also include restitution and disgorgement. Restitution of tax and other benefits received by the property owner on account of the servitude and disgorgement of profits reaped from violation of the servitude may be awarded in appropriate cases.

This section, in combination with $\S 7.11$, is designed to protect the long-term utility of conservation servitudes by encouraging courts to enforce them as vigorously as possible and by discouraging servient owners from engaging in conduct that lessens the effectiveness of the servitude or frustrates its purpose. ${ }^{70}$

\section{G. Adverse Possession, Laches, Estoppel, and Waiver}

New York's enabling statute provides: "Enforcement shall not be defeated because of any subsequent adverse possession, laches, estoppel or waiver." ${ }^{, 71}$

\footnotetext{
${ }^{70}$ Restatement (ThiRd) OF Property: Servitudes $\S 8.5 \mathrm{cmt}$. a (2000).

${ }^{71}$ N.Y. ENVTL. CONSERV. § 49-0305.5. See also Weston Forest and Trail Association, Inc. v. Fishman, 849 N.E.2d 916 (Mass. App. Ct. 2006) (neither laches nor estoppel barred a local land trust from enforcing a conservation easement; the court recognized that both government entities and land trusts enforce conservation easements on behalf of the public, and, thus, neither should be barred from doing so on the grounds of laches or estoppel); Feduniak v. California Coastal Commission, 148 Cal. App. 4th 1346 (2007) (neither laches nor estoppel barred the California Coastal Commission from ordering coastal homeowners to comply with the terms of a conservation easement by removing a private three-hole pitch-and-putt golf course from around their house and restoring the area to its native sand dune vegetation even though the homeowners had no notice of the easement because the sellers failed to disclose it and the title company failed to disclose it in the title report; the owner's loss of enjoyment could not outweigh the public's strong interest in (i) eliminating an ongoing unpermitted development, which violated applicable restrictions and had done so for over 20 years; (ii) finally restoring the area to its natural state and native vegetation; and (iii) protecting the Commission's ability to enforce existing and future easement and permit conditions).
} 
Rhode Island, in a separate part of its Code, provides: "Any land held or preserved by a nonprofit corporation or nonprofit association for purposes of conservation, open space, or a cemetery is not subject to adverse possession or prescription." ${ }^{, 72}$

Arizona's statute, on the other hand, provides that a conservation easement is subject to the laws relating to adverse possession. ${ }^{73}$

\section{H. Attorneys Fees and Costs}

A number of the enabling statutes contain provisions addressing the payment of attorneys' fees and costs.

California's statute provides:

The court may award to the prevailing party in any action authorized by this [enforcement of easement] section the costs of litigation, including reasonable attorney's fees. ${ }^{74}$

Rhode Island's statute provides:

The court in any judicial proceeding, or the decision maker in any arbitration or other alternative dispute resolution proceeding, in addition to any other relief ordered, may award the prevailing party, reasonable attorneys' fees and costs incurred in the action or proceeding. $^{75}$

The Massachusetts statute provides:

If the court in any judicial enforcement proceeding, or the decision maker in any arbitration or other alternative dispute resolution enforcement proceeding, finds there has been a violation of the restriction..., in addition to any other relief ordered, the petitioner bringing the action or proceeding may be awarded reasonable attorneys' fees and costs incurred in the action proceeding. ${ }^{76}$

The Massachusetts provision is more protective of easement holders because it provides for the award of attorneys' fees and costs only to the petitioner bringing an enforcement proceeding if the court finds there has been a violation of an easement.

\section{Back-Up Holder}

Nonprofit holders of conservation easements include well-funded organizations that operate both nationally and internationally (The Nature Conservancy), regional and state-wide organizations, and smaller, local organizations, some of which are all-volunteer and have little

\footnotetext{
${ }^{72}$ R.I. GEN. LAWS $§ 34-7-9$.

73 ARIZ. REV. STAT. ANN. § 33-275.2.

${ }^{74}$ CAL. Civ. CoDE $§ 815.7($ d). Hawaii has the same provision. HAW. REv. STAT. ANN. $§ 198-5(d)$.

${ }^{75}$ R.I. GEN. LAWS $§$ 34-39-3(e).

${ }^{76}$ MASS. GEN. LAWS ANN. ch. 184, § 32.
} 
funding or other resources. In addition, developers or promoters of conservation easement transactions sometimes create nonprofit organizations to hold easements and such organizations may have no staff or funding and are not viable over the long term. Accordingly, some organizations holding easements have and will become defunct, leaving "orphaned" easements. Although the state attorney general is the official charged in most states with oversight of charities and their assets, in some jurisdictions the attorney general may not be aware of orphaned easements or may not have the resources or capacity to handle such easements.

Three enabling statutes address the issue of a back-up holder for orphaned easements, albeit in different ways.

Iowa: "A conservation easement may be held by a private, nonprofit organization for public benefit if the instrument granting the easement or the bylaws of the organization provide that the easement will be transferred either to a public body or another private, nonprofit organization upon the dissolution of the private, nonprofit organization."77

Pennsylvania: "To the extent the easement is in gross, the easement shall be transferred to a willing successive holder, should the original holder or successive holder be dissolved or otherwise cease to exist, in order to accomplish the goal of the easement. If a willing successive holder cannot be identified, the municipality in which the easement is located shall automatically become the successive holder for perpetuity or the remaining term of the easement."

Virginia: "Whenever any holder as defined in this chapter, or the successors or assigns thereof, shall cease to exist, any conservation easement and any right of enforcement held by it shall vest in the Virginia Outdoors Foundation, unless the instrument creating the easement otherwise provides for its transfer to some other holder or public body. In an easement vested in the Virginia Outdoors Foundation by operation of the preceding sentence, the Foundation may retain it or thereafter convey it to any other public body or any holder the Foundation deems most appropriate to hold and enforce such interest in accordance with the purpose of the original conveyance of the easement."79

Maryland's enabling statute provides for a back-up holder at the creation of an easement:

If any grant, reservation, dedication, devise, or gift of any nature which clearly indicates the maker's intention to subject any interest or estate in property to public use for the preservation of agricultural, historic, or environmental qualities fails to specify a grantee, donee, legatee, or beneficiary to receive the same or specifies a grantee, donee, legatee, or beneficiary who is not legally capable of taking the interest or estate, it passes to the Maryland Agricultural Land Preservation Foundation, the Maryland Historical Trust, or

\footnotetext{
77 IOWA CODE ANN. § 457A.8.

7832 PA. CONS. STAT. ANN. § 5054(d).

79 VA. CODE ANN. $§ 10.1-1015$. The Virginia Outdoors Foundation (VOF) is a quasi-state agency that holds open space conservation easements created under Virginia's other enabling statute. Most of the easements created in Virginia are open space easements held by the VOF.
} 
the Maryland Environmental Trust in any proceedings under $\S \S 14-301$ and 14-302 of the Estates and Trusts Article. ${ }^{80}$

In addressing the issue of a back-up holder, consideration should be given to: (i) the federal and state laws applicable to the distribution of the assets of a charitable organization upon its dissolution; (ii) any requirements that must be met for easement grantors to be eligible for federal tax incentives and other subsidies, such as the "restriction on transfer" requirement that must be met for the donation of a conservation easement to be eligible for a federal charitable income tax deduction; ${ }^{81}$ (iii) whether the transfer provision in the statute should be a default rule that yields to contrary terms in an easement deed; and (iv) the reluctance of government and charitable entities to assume responsibility for conservation easements that may not be consistent with their conservation missions, drafted in accordance with their standards, or accompanied by funding for stewardship. Orphaned easements and the state's role as the default ultimate back-up holder could cause states to consider developing easement guidelines, criteria, and forms (as Massachusetts has done) to ensure some level of quality and consistency in the easements created in the state.

\section{J. Eminent Domain ${ }^{82}$}

A number of the enabling statutes expressly prohibit or limit the creation of conservation easements by eminent domain. ${ }^{83}$

On the other hand, a number of enabling statutes expressly provide that conservation easements may be taken (i.e., altered or extinguished) by eminent domain. ${ }^{84}$ Even in states with

\footnotetext{
${ }^{80}$ MD. CODE ANN., REAL PROP. $§ 2-118(\mathrm{e})$.

${ }^{81}$ Treas. Reg. $\S 1.170 \mathrm{~A}-14$ (c)(2) (requiring that the instrument of conveyance prohibit the transfer of the easement except to another "eligible donee" that agrees to continue to carry out the conservation purposes of the easement); $i d$. $\S 1.170 \mathrm{~A}-14(\mathrm{c})(1)$ (defining "eligible donee" as a "qualified organization" that has "a commitment to protect the conservation purposes of the donation, and . . . the resources to enforce the restrictions"); I.R.C. § 170(h)(3)(C) (defining "qualified organization" to include government entities and publicly-supported charities and satellites thereof).

${ }^{82}$ For articles discussing eminent domain in the conservation easement context, see Levin, When Forever Proves Fleeting: The Condemnation and Conversion of Conservation Land, 9 N.Y.U. ENVT'L L.J. 592 (2001); McLaughlin, Condemning Conservation Easements: Protecting the Public Interest and Investment in Conservation, 41 U.C. DAVIS L. REV. 1897 (2008).

${ }^{83}$ See, e.g., GA. CODE ANN. § 44-10-3(a) ("a conservation easement may not be created or expanded by the exercise of the power of eminent domain"); TENN. CODE ANN. § 66-9-305(a) ("No conservation easement shall be acquired by eminent domain unless such easement is necessary for the accomplishment of a specific public project which has been authorized by statute."). See also, e.g., ARIZ. REV. STAT. ANN. § 33-272.A ("For purposes of this article, conservation easements shall be voluntarily created and shall not be required by a political subdivision or governmental entity."); CAL. CIV. CODE $\S 815.3$ (b) ("No local governmental entity may condition the issuance of an entitlement for use on the applicant's granting of a conservation easement pursuant to this chapter.").

${ }^{84}$ See, e.g., ALA. CODE $§ 35-18-2$ (c) ("Nothing in this chapter shall be construed to impair or diminish in any way the rights of any person, entity, or governmental body authorized by the laws of this state or under federal law to acquire property interests through the exercise of eminent domain or condemnation. A conservation easement may be condemned or appropriated through eminent domain in the same manner as any other property interest."); HAW. REV. STAT. ANN. § 198-6 ("Nothing in this chapter shall diminish the powers granted by any general or special law to acquire, by purchase, gift, eminent domain, or otherwise, and to use land for public purposes."); S.C. CODE ANN. $\S$ 27-8-80 ("A person or entity empowered to condemn may condemn a conservation easement for other public purposes pursuant to applicable provisions of the 1976 Code or federal law.”); WYO. STAT. ANN. § 34-1-207(a) ("Conservation
} 
enabling statutes that do not address the issue, it is generally assumed that conservation easements, like other interests in real property, may be taken by eminent domain. ${ }^{85}$

\section{(i) Limited Protections in Enabling Statutes}

A number of the enabling statutes grant limited protections to conservation easements in the eminent domain context.

For example, Florida's statute provides:

In any legal proceeding to condemn land for the purpose of construction and operation of a linear facility, the court shall consider the public benefit provided by the conservation easement and linear facilities in determining which lands may be taken and the compensation paid. ${ }^{86}$

The Massachusetts statute provides:

Nothing in this section shall prohibit the department of public utilities or the department of telecommunications and cable from authorizing the taking of easements for the purpose of utility services provided...said department shall require the minimum practicable interference with farming operations with respect to width of easement, pole locations and other pertinent matters. ${ }^{87}$

New York's statute provides:

easements shall be subject to the state's power of eminent domain in the same manner as any other real property interest.").

${ }^{85}$ See ReStatement (Third) OF Property: Servitudes $\S 7.8 \mathrm{cmt}$. a (2000) ("Servitude benefits like other interests in property may be condemned under the power of eminent domain.”); RICHARD R. POWELL, POWELL ON REAL PROPERTY § 34A.07[2] (Michael Allan Wolf ed., 2007) (“...if a conservation easement restricts the development of real property that is needed for a school, hospital, or publicly aided housing, eminent domain may be exercised."); Hassman, Annotation, Eminent Domain: Right to Condemn Property Owned or Used by Private Educational, Charitable, or Religious Organization, 80 A.L.R.3d 833, §2[a] (1996) ("The fact that property is owned or used by a private educational, charitable, or religious organization has not ordinarily, in itself, served to protect the property from being taken under an eminent domain power."). However, in Texas Eastern Transmission Corp. v. Wildlife Preserves, 225 A.2d 130 (1966) the court held that the quantum of proof required by a nonprofit conservation organization to show arbitrariness on the part of the condemning authority should not be as substantial as in the case of an ordinary property owner who devotes his land to conventional uses. Wildlife Preserves devoted its property to the conservation and preservation of wildlife, and the court explained that such a purpose is encouraged and often engaged in by government itself. This gave Wildlife Preserves a somewhat more potent claim to judicial protection against the taking of its preserve or a portion of it by arbitrary action of a condemnor. "In such unique cases courts realize that more than a dollar valuation is involved. The public service being rendered must be considered and it cannot be evaluated adequately only in dollars and cents." On remand, however, the higher standard did not preclude condemnation. Texas Eastern Transmission Corp. v. Wildlife Preserves, 230 A.2d 505 (1967).

86 Fla. STAT. ANN. $§$ 704.06(11). Linear facilities include electric transmission and distribution facilities, telecommunications transmission and distribution facilities, pipeline transmission and distribution facilities, public transportation corridors, and related appurtenances.

${ }^{87}$ MASS. GEN. LAWS ch. 184, § 32 . 
Where a conservation easement is modified or extinguished pursuant to [certain eminent domain actions], such easement shall be modified or extinguished only to the minimum extent necessary to accommodate the facility which is the subject of the certificate of environmental compatibility and public need. ${ }^{88}$

Rhode Island's statute provides:

Any state or local agency that is exercising a right of eminent domain over any land which is protected with a conservation restriction or preservation restriction shall notify the agency or organization that holds the conservation or preservation restriction and the Rhode Island department of environmental management at the same time they are notifying fee property owners of their intentions to condemn the properties. Such notification shall include an explanation of the public purpose for which the land protected by the conservation or preservation restriction is being condemned. ${ }^{89}$

South Carolina's statute provides:

Holders of the conservation easement must be parties to the proceedings along with the owner of the land. ${ }^{90}$

\section{(ii) Protections in Agricultural Easement Statutes}

A number of states have statutes governing the creation of agricultural easements. Some of these statutes grant significant protections to the easements in the eminent domain context. For example, the Rhode Island Farmland Preservation Act provides:

Any state or local agency must demonstrate extreme need and the lack of any viable alternative before exercising a right of eminent domain over any farmland to which the development rights have been purchased by the commission on behalf of the state, or which has been designated as agricultural land in the agricultural land preservation program by the commission. The agency will file a separate report with the commission showing the necessity of condemning this land. The report must be endorsed by the governor after public hearings. If the commission feels that cause has not been adequately demonstrated, it shall have recourse to the superior court for a decision on the matter. ${ }^{91}$

In many cases, the agricultural easements are purchased in whole or in part with state funds, which may, in part, explain the greater protections.

\footnotetext{
${ }^{88}$ N.Y. ENVTL. CONSERV. § 49-0307.4. New York's statute provides other limited protections to conservation easements in particular areas. See, e.g., id. § 49-0307.3(e).

${ }^{89}$ R.I. GEN. LAWS § 34-39-6.

${ }^{90}$ S.C. CODE ANN. § 27-8-80.

${ }^{91}$ R.I. GEN. LAwS $\S 42-82-6$.
} 


\section{(iii) Compensation to Holder}

A number of the enabling statutes address whether a conservation easement constitutes a compensable property interest for eminent domain purposes, albeit in very different ways. ${ }^{92}$

For example, Virginia's statute provides:

This chapter does not...in any way limit the power of eminent domain as possessed by any public body. In any such proceeding the holder of the conservation easement shall be compensated for the value of the easement. ${ }^{93}$

Pennsylvania's statute provides:

In the event of exercise of eminent domain, nothing in this act shall be construed so as to restrict any right to compensation a holder of a conservation or preservation easement may have under applicable law. ${ }^{94}$

Just compensation.--A court order...shall provide for the holder of the easement to be compensated in accordance with the applicable provisions of the conservation or preservation easement which specify a particular allocation of damages and, in the absence of such a provision, for the fair market value of the easement. Nothing in this act shall be construed to prevent a purchase agreement in lieu of condemnation as a means of settling such claims by providing either the specifically allocated damages or the fair market value to the holder of the easement. The net proceeds of the condemnation received by the holder shall be applied in furtherance of the public benefit in accordance with its charter or articles of incorporation. The court in adjudicating damages to a conservation or preservation easement shall be guided by principles generally applicable to condemnation proceedings. ${ }^{95}$

Virginia's Open-Space Land Act contains a provision governing the "conversion or diversion" of land subject to an open space easement held by a public body:

No open-space land, the title to or interest or right in which has been acquired under this chapter and which has been designated as open-space land under the authority of this chapter, shall be converted or diverted from open-space land use unless

(i) the conversion or diversion is determined by the public body to be

(a) essential to the orderly development and growth of the locality and

(b) in accordance with the official comprehensive plan for the locality in effect at the time of conversion or diversion and

(ii) there is substituted other real property which is

\footnotetext{
92 In forty-nine states and the District of Columbia conservation easements are identified in the enabling statute as interests in real property or land. In the remaining state, Illinois, they are identified as such in case law. See Libertyville v. Connors, 185 Ill. App. 3d 317, 330- 31 (App. Ct. 1989).

${ }^{93}$ VA. CODE ANN. $§ 10.1-1010(\mathrm{~F})$. The Virginia statute does not address how to calculate the "value" of an easement. 9432 Pa. CONS. STAT. AnN. $§ 5055(d)(2)$.

${ }^{95}$ Id. $\S 5055(\mathrm{e})$. The Pennsylvania statute does not address how to calculate the "fair market value" of an easement.
} 
(a) of at least equal fair market value,

(b) of greater value as permanent open-space land than the land converted or diverted and

(c) of as nearly as feasible equivalent usefulness and location for use as permanent open-space land as is the land converted or diverted.

The public body shall assure that the property substituted will be subject to the provisions of this chapter. ${ }^{96}$

Nebraska's statute provides:

If property subject to a conservation or preservation easement is condemned for public use, that part of the easement which conflicts with the condemnation shall terminate as of the time of the condemnation. If the easement was obtained by gift or devise the owner shall be entitled to such compensation for the taking as if the property had not been subject to the easement and if the easement was obtained by purchase or exchange, the holder shall be entitled to just compensation for the taking of the easement. ${ }^{97}$

Given that a conservation easement that is conveyed by gift or devise is a charitable asset held for the benefit of the public, and the grantor or the grantor's estate may have received tax benefits for the donation, there seems little justification for Nebraska's provision denying just compensation to the holder upon the condemnation of such an easement.

A number of other enabling statutes deny or appear to deny compensation to the holder of a conservation easement. The Massachusetts statute provides that, upon the taking of easementencumbered land for utility services purposes, "the applicant shall compensate the owner of the property in the same manner and the same fair market value as if the land were not under restriction." 98 Maryland eminent domain law similarly provides that if a conservation easement has been donated to either the Maryland Historical Trust or the Maryland Environmental Trust (both of which are state agencies that acquire conservation easements), "damages shall be awarded in any condemnation proceedings under this title to the fee owner and leasehold owner, as their interests may appear, and shall be the fair market value of the land or interest in it, computed as though the easement or other right did not exist." 99 This provision was intended to guard against the danger that condemning authorities might try to acquire easement-encumbered lands for their restricted value, which would make such lands even more attractive targets for condemnation. ${ }^{100}$ Ensuring that condemning authorities are required to pay full value for the property they acquire when condemning easement-encumbered land is a laudable goal. However, the Massachusetts and Maryland provisions could have been drafted to require that the share of the condemnation award attributable to the easement be allocated to the holder.

\footnotetext{
96 VA. CodE ANN. $§ 10.1-1704$.A. Montana's enabling statute has a somewhat similar provision. See MoNT. CoDE ANN. § 76-6-107.

${ }^{97}$ NEB. REV. STAT. $§ 76-2,117$.

${ }^{98}$ MASS. GEN. LAWS ch. 184, $§ 32$.

${ }^{99}$ Md. CODE ANN., REAL PROP. § 12-104(g).

100 See McLaughlin, Condemning Conservation Easements, Protecting the Public Interest and Investment in Conservation, 41 U.C. DAVIS L. REV. 1897, 1963-64 (2008).
} 
The Arizona statute provides that a conservation easement is "subject to the acquisition of real property interests under the laws of this state governing eminent domain, except that the existence of a conservation easement shall not be considered an additional interest in real property for which compensation or damages may be awarded under the laws pertaining to eminent domain." 101 The West Virginia statute provides that "Nothing in this article may be construed to limit the lawful exercise of the right of eminent domain..., or the right of any real property owner to compensation by reason of the lawful exercise of such right of eminent domain...for any estate or interest in real property except a conservation or preservation easement authorized by this article." 102 The Kentucky statute provides that "[a] conservation easement...shall not operate to impair or restrict any right or power of eminent domain created by statute, and all such rights and powers shall be exercisable as if the conservation easement did not exist."103

\section{(iv) Additions to Eminent Domain Laws}

At least three states relatively recently added provisions addressing the condemnation of conservation easements to their eminent domain laws.

The Illinois Eminent Domain Act provides:

The right to just compensation, as provided in this Act, applies to property subject to a conservation right under the Real Property Conservation Rights Act. The amount of compensation for the taking of the property shall not be diminished or reduced by virtue of the existence of the conservation right. The holder of the conservation right shall be entitled to just compensation for the value of the conservation right. ${ }^{104}$

North Carolina's eminent domain law provides, with some exceptions, that a public entity that acts to exercise the power of eminent domain on property encumbered by a conservation easement must provide a statement that alleges that there is no prudent and feasible alternative. ${ }^{105}$ If the holder of the easement contests the proposed exercise of eminent domain, a judge must determine whether a prudent and feasible alternative exists, and the burden of persuasion is on the condemnor if the holder of the easement, after discovery, identifies at least one alternative. ${ }^{106}$ If the judge determines that a prudent and feasible alternative exists, the court must dismiss the action and award the holder of the easement costs, disbursements, and expenses other than attorneys' fees. ${ }^{107}$ In any action to condemn property encumbered by a conservation easement, the court must determine just compensation by first determining the value of the property taken as a whole, unencumbered by the conservation easement, as well as any other, separately owned interest in the property. ${ }^{108}$ The court must then allocate the compensation award between or among any holders of the conservation easement and any owners of the property as provided by the easement

\footnotetext{
101 ARIZ. REV. STAT. ANN. § 33-275.3.

${ }^{102}$ W. VA. CODE $§ 20-12-5(c)$.

${ }^{103}$ KY. REV. STAT. ANN. $§ 382.850(2)$.

104735 Ill. COMP. STAT. ANN. 30/10-5-5(b) (effective Jan. 1, 2007). A conservation easement is referred to as a "conservation right" in the Illinois enabling statute.

${ }^{105}$ N.C. GEN. STAT. § 40A-81 (effective Oct. 1, 2009).

${ }^{106}$ Id. $\S 40 \mathrm{~A}-82(\mathrm{~b})$.

${ }^{107} \mathrm{Id}$.

${ }^{108}$ Id. $\S 40 \mathrm{~A}-84$.
} 
agreement or, if the agreement fails to address the issue, as the judge finds equitable based upon evidence, which must include the opinion of a real estate valuation expert with experience in the valuation of conservation easements. ${ }^{109}$

California's eminent domain law requires that condemning authorities make a special showing of necessity when condemning a conservation easement that qualifies as "property appropriated to public use" - generally a conservation easement held by a public entity, purchased in part with public funds, or acquired as a result of a development approval or permitting process. ${ }^{110}$ The law requires a condemning authority to provide the holder of a conservation easement with notice of the taking and an opportunity to provide written comments on the acquisition, including identifying any potential conflict between the proposed public use of the property and the purposes and terms of the conservation easement. ${ }^{111}$ Public entities that helped purchase the easement, or that granted permits, variances, or other approvals in exchange for the easement, must also be provided notice of the proceeding and an opportunity to participate. ${ }^{112}$ The holder must be named as a defendant in the proceeding and has all the same rights and obligations as any other defendant. ${ }^{113}$ The law also provides that the holder of a conservation easement is the owner of an interest in property for which it must be compensated, and compensation must generally be determined in the same manner as it is determined with regard to the condemnation of other types of properties where the ownership is divided. ${ }^{114}$

\section{K. Merger, Marketable Title Acts, and Tax Lien Laws}

\section{(i) Broad Provisions}

New York's enabling statute contains the following broad provision, which could be interpreted to mean that the doctrine of merger and the state's marketable title act and tax lien laws do not operate to defeat a conservation easement in the state.

No general law of the state which operates to defeat the enforcement of any interest in real property shall operate to defeat the enforcement of any conservation easement unless such general law expressly states the intent to defeat the enforcement of such easement or provides for the exercise of the power of eminent domain. ${ }^{115}$

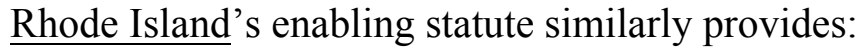

\footnotetext{
${ }^{109} \mathrm{Id}$.

${ }^{110}$ See CAL. CIV. Proc. CodE $\S 1240.055($ a)(3) (effective Jan. 1, 2012). See also id. $\S 1240.610$ (authorizing the use of eminent domain to acquire "property appropriated to public use" only if the new use is a more necessary public use).

${ }^{111} I d . \S 1240.055(\mathrm{c})(3)$.

${ }^{112} I d . \S 1240.055(\mathrm{c})(2)$.

${ }^{113}$ Id. $\S 1240.055(\mathrm{f})$.

${ }^{114}$ Id. $\S 1240.055(\mathrm{~g})$.

${ }^{115}$ N.Y. ENVTL. CONSERV. § 49-0305.5.
} 
No conservation restriction...shall be unenforceable against any owner of the restricted land...on account of any...doctrine of property law which might cause the termination of the restriction such as, but not limited to, the doctrine of merger and tax delinquency. ${ }^{116}$

Other states have addressed merger, marketable title, and tax lien issues separately in their enabling statutes or other parts of their state codes.

\section{(ii) Merger}

Although merger arguably does not apply in most cases when the holder of a conservation easement acquires fee title to the land (because the unity of ownership required for merger will not be present),${ }^{117}$ the enabling statutes in the following states preclude (or appear to preclude) merger.

Mississippi: "A conservation easement shall continue to be effective and shall not be extinguished if the easement holder is or becomes the owner in fee of the subject property." 118

Maine: "A conservation easement is valid even though...[t]he title to the real property subject to the conservation easement has been acquired by the holder, unless the holder, with the consent of any 3rd party with rights of enforcement, replaces the conservation easement with legally binding restrictions under a conservation easement or declaration of trust at least as protective of the conservation values of the protected property as provided by the replaced easement." 119

Tennessee: "A conservation easement shall remain severed from the fee unless returned by specific conveyance to the holder of the fee." 120

In Montana, the following appears in the servitudes section of the state's Code:

${ }^{116}$ R.I. GEN. LAWS § 34-39-3(a).

117 See, e.g., McLaughlin, Conservation Easements and The Doctrine of Merger, 74 DuKE J.L. \& CONTEMP. PROBS. 279 (2011); Opinion of the Virginia Attorney General (Aug. 31, 2012) (on file with author); STEPHEN J. SMALL, THE FEDERAL TAX LAW OF CONSERVATION EASEMENTS E-5 ("Many states have statutes of charitable uses, the effect of which might be to bar merger."). Professor Wolf notes:

There seems to be little logic and a lot of bad public policy behind application of this traditional rule [of merger] to easements that are designed to be perpetual and in the public interest. The identity of the owner of the property subject to a conservation restriction is irrelevant to the purpose of the restriction. It would be unfortunate if the grantor's intent were frustrated by a government or nonprofit holder that had the good fortune of being the beneficiary of a partial interest in year one, and in year twenty of the underlying fee, particularly if that entity, which would now own the property free of restrictions, sought to sell it for development, trade it for another parcel, or otherwise use the property for non-conservation purposes.

Wolf, Conservation Easements and the “Term Creep” Problem, 2013 UTAH L. REV. 787, 803-04.

${ }^{118}$ Miss. CODE ANN. § 89-19-5(5).

${ }^{119}$ Me. Rev. Stat. AnN. tit. 33, § 479.10. For a discussion of this provision, see McLaughlin \& Pidot, Conservation Easement Enabling Statutes: Perspectives on Reform, 2013 UTAH L. REV. 811, 836.

120 TENN. CODE ANN. § 66-9-304(a). 
A conservation easement may not be extinguished by taking fee title to the land to which the conservation easement is attached. ${ }^{121}$

\section{(iii) Marketable Title Acts}

The enabling statutes in the following states provide that conservation easements will not be defeated by the state's marketable title act.

Illinois: "The holder of a grant pursuant to this Act shall not be required to record any instrument subsequent to the recording of the grant in order to maintain or continue the validity of the grant."122

Iowa: "A conservation easement shall be enforceable during the term of the easement notwithstanding [Iowa's marketable title act].",123

Rhode Island: "The restrictions shall not be subject to the thirty year limitation on restrictive covenants provided in $\S 34-4-21 ., " 124$

Vermont: "A document creating such a [conservation] right or interest...shall not be subject to the requirement of filing a notice of claim within the 40 -year period as provided in [Vermont's marketable title act]."125

Florida's enabling statute, on the other hand, provides:

An owner of property encumbered by a conservation easement must abide by the requirements of [the state's marketable title act] or any other similar law or rule to preserve the conservation easement in perpetuity. ${ }^{126}$

A number of states include an express exception for conservation easements in the marketable title section of the state's Code. ${ }^{127}$

\section{(iv) Tax Lien Laws}

The enabling statutes in the following states provide that conservation easements will not be terminated as a result of tax liens.

\footnotetext{
${ }^{121}$ Mont. CODE ANN. § 70-17-111(2).

122765 Ill. Comp. StAT. ANN. 120/1(b).

${ }^{123}$ IOWA CODE ANN. $§ 457$ A.2.1.

124 R.I. GEN. LAWS § 34-39-3(c).

${ }^{125}$ VT. STAT. ANN. tit. 10, $\$ 823$.

${ }^{126}$ FLA. STAT. ANN. $\S 704.06(12)$.

127 See, e.g., CAL. CiV. CODE $§ 880.240(\mathrm{~d})$; MASS. Gen. LAWs ANN. ch. 184, $\S \S 26,27$; WiS. STAT. $\S 893.33(6 \mathrm{~m})$. See also RESTATEMENT (THIRD) OF PROPERTY: SERVITUDES $§ 7.16$ (2000) (recommending exemption of conservation servitudes from application of marketable title acts); McStotts, In Perpetuity or for Forty Years, Whichever Is Less: The Effect of Marketable Record Title Acts on Conservation and Preservation Easements, 27 J. LAND RESOURCES \& ENVTL. L. 41 (2007).
} 
Florida: "Notwithstanding the provisions of s. 197.552, all provisions of a conservation easement shall survive and are enforceable after the issuance of a tax deed."

Maine: "A conservation easement is valid even though...[a] lien has been established for property tax delinquency...or title to the real property subject to the conservation easement has been acquired by procedures for enforcement and foreclosure of delinquent taxes...."

At least two states provide in the property tax section of the state's Code that conservation easements will not be terminated as a result of tax liens. ${ }^{130}$

\section{Property Tax Assessments}

Numerous enabling statutes provide that land subject to a conservation easement must be assessed at its restricted value for property tax purposes. The following are examples.

California: "A conservation easement granted pursuant to this chapter constitutes an enforceable restriction, for purposes of [the assessment of land for property taxation purposes]." $" 131$

Colorado: "Conservation easements in gross shall be subject to assessment, taxation, or exemption from taxation in accordance with general laws applicable to the assessment and taxation of interests in real property. Real property subject to one or more conservation easements in gross shall be assessed, however, with due regard to the restricted uses to which the property may be devoted. The valuation for assessment of a conservation easement which is subject to assessment and taxation, plus the valuation for assessment of lands subject to such easement, shall equal the valuation for assessment which would have been determined as to such lands if there were no conservation easement." ${ }^{, 132}$

Georgia: "A conservation easement may be recorded in the office of the clerk of the superior court of the county where the land is located. Such recording shall be notice to the board of tax assessors of such county of the conveyance of the conservation easement and shall entitle the owner to a revaluation of the encumbered real property so as to reflect the existence of the encumbrance on the next succeeding tax digest of the county. Any owner who records a conservation easement and who is aggrieved by a revaluation or lack thereof under this Code section may appeal to the board of equalization and may appeal from the decision of the board of equalization in accordance with Code Section 48-5-311." ${ }^{, 133}$

Nebraska: "Real property subject to a conservation or preservation easement shall be assessed with due regard to the restricted uses to which the property may be devoted. The conservation or preservation easement in the hands of the holder shall be subject to

\footnotetext{
${ }^{128}$ FLA. STAT. ANN. $\S 704.06(4)$.

${ }^{129}$ ME. REV. StAT. AnN. tit. 33, § 479.9.

${ }^{130}$ See Colo. ReV. StAT. § 39-11-136(3); 35 Ill. Comp. Stat. AnN. 200/22-70.

131 CAL. Civ. Code $\S 815.10$; CAL. ReV. AND TAX. CODE $\S$ 402.1(a).

132 COLO. REV. STAT. $\S 38-30.5-109$.

${ }^{133}$ GA. CODE ANN. $§ 44-10-8$.
} 
assessment, taxation, or exemption from taxation in accordance with general laws applicable to assessment and taxation of interests in real property.",134

New Jersey: "The existence of any conservation restriction or historical preservation restriction acquired pursuant to this act shall be considered by local assessors in establishing the full value of any lands subject to such restriction.",135

Oregon: "For the purpose of taxation, real property that is subject to a highway scenic preservation easement shall be assessed on the basis of the real market value of the property less any reduction in value caused by the highway scenic preservation easement. Such an easement shall be exempt from assessment and taxation the same as any other property owned by the holder."136

South Carolina: "For ad valorem tax purposes real property that is burdened by a conservation easement must be assessed and taxed on a basis that reflects the existence of the easement."137

Tennessee: "When a conservation easement is held by a public body or exempt organization for the purposes of this chapter, the subject real property shall be assessed on the basis of the true cash value of the property or as otherwise provided by law, less such reduction in value as may result from the granting of the conservation easements....The value of the easement interest held by the public body or exempt organization shall be exempt from property taxation to the same extent as other public property."138

The enabling statutes in Montana and Wyoming provide a minimum assessed value for land subject to a conservation easement:

Montana: "Assessments made for taxation on property subject to a conservation easement...shall be determined on the basis of the restricted purposes for which the property may be used. The minimum assessed value for land subject to an easement conveyed under this chapter may not be less than the actual assessed value of such land in calendar year 1973. Any land subject to such easement may not be classified into a class affording a lesser assessed valuation solely by reason of the creation of the easement. The value of the interest held by a public body or qualifying private organization shall be exempt from property taxation." $" 139$

Wyoming: "The real property tax imposed upon real property subject to a conservation easement shall not be less than the amount of the ad valorem tax for the property had it

\footnotetext{
${ }^{134}$ NEB. REV. STAT. § 76-2,116.

${ }^{135}$ N.J. STAT. ANN. § 13:8B-7.

136 OR. REV. STAT. $§ 271.785$. The Oregon statute also provides that an owner considering whether to convey a conservation easement can apply to the county assessor for a report on the effect the conveyance would have on the assessed value of the subject property. Id. $\S 271.729$.

${ }^{137}$ S.C. CODE ANN. $\S 27-8-70$.

138 TENN. CODE ANN. $\$ 66-9-308$.

${ }^{139}$ Mont. Code ANN. § 76-6-208(1).
} 
been levied and assessed based upon the taxable value of agricultural land of similar productive use and value under W.S. 39-13-101(a)(iii) and 39-13-103(b)(x)."140

By providing for a recapture tax, the Texas enabling statute implicitly acknowledges that land subject to a conservation easement will be assessed at its restricted value:

If land that has been subject to a conservation easement is no longer subject to such easement, an additional tax is imposed on the land equal to the difference, if any, between the taxes imposed on the land for each of the five years preceding the year in which the easement terminates and the taxes that would have been imposed had the land not been subject to a conservation easement in each of those years, plus interest at an annual rate of seven percent calculated from the dates on which the differences would have become due. ${ }^{141}$

The enabling statute in Virginia provides for land subject to an easement to be assessed at its restricted or its open space value, depending on the circumstances.

A. Where an easement held pursuant to this chapter or the Open-Space Land Act...by its terms is perpetual, neither the interest of the holder of a conservation easement nor a thirdparty right of enforcement of such an easement shall be subject to state or local taxation nor shall the owner of the fee be taxed for the interest of the holder of the easement.

B. Assessments of the fee interest in land that is subject to a perpetual conservation easement held pursuant to this chapter or the Open-Space Land Act...shall reflect the reduction in the fair market value of the land that results from the inability of the owner of the fee to use such property for uses terminated by the easement. To ensure that the owner of the fee is not taxed on the value of the interest of the holder of the easement, the fair market value of such land (i) shall be based only on uses of the land that are permitted under the terms of the easement and (ii) shall not include any value attributable to the uses or potential uses of the land that have been terminated by the easement.

C. Notwithstanding the provisions of subsection B, land which is (i) subject to a perpetual conservation easement held pursuant to this chapter or the Open-Space Land Act..., (ii) devoted to open-space use as defined in $§ 58.1-3230$, and (iii) in any county, city or town which has provided for land use assessment and taxation of any class of land within its jurisdiction pursuant to $\S 58.1-3231$ or $\S 58.1-3232$, shall be assessed and taxed at the use value for open space, if the land otherwise qualifies for such assessment at the time the easement is dedicated. If an easement is in existence at the time the locality enacts land use assessment, the easement shall qualify for such assessment. Once the land with the easement qualifies for land use assessment, it shall continue to qualify so long as the locality has land use assessment. ${ }^{142}$

\footnotetext{
${ }^{140}$ WyO. STAT. ANN. § 34-1-207(b).

141 TEX. NAT. RES. CODE ANN. $§ 183.002(f)$.

${ }^{142}$ VA. CODE ANN. $\S 10.1-1011$.
} 
A number of states provide in the property tax section of the state's Code that land subject to a conservation easement may or must be assessed at its restricted value. ${ }^{143}$ New York's Tax Law grants taxpayers who own land subject to a conservation easement a credit for $25 \%$ of the property taxes on the land, subject to an annual cap of $\$ 5,000 .{ }^{144}$ The Illinois Property Tax Code provides that land subject to a conservation easement can be valued at a set percentage of its unrestricted value provided the easement meets certain requirements. ${ }^{145}$

Because some jurisdictions already provide for the assessment of land at its open space or agricultural value, favorable property tax assessment provisions may have little practical effect. Moreover, determining the restricted value of land can be difficult given the generally highly individualized use restrictions in conservation easements and the fact that such restrictions may be altered over time by, for example, amendments, discretionary approvals, or temporary permitted use agreements. The difficulties associated with valuing easement-encumbered land suggests that some sort of formulaic discount as in New York or Illinois may be preferable.

Idaho's enabling statute stands alone in providing that the existence of a conservation easement shall not have any effect on the value of the subject property for tax assessment purposes.

The granting of a conservation easement across a piece of property shall not have an effect on the market value of property for ad valorem tax purposes and when the property is assessed for ad valorem tax purposes, the market value shall be computed as if the conservation easement did not exist. ${ }^{146}$

\section{Duration, Amendment, and Extinguishment}

The rules governing the duration, amendment, and extinguishment of conservation easements have been the subject of controversy and much has been written on the topic. ${ }^{147}$ This

\footnotetext{
${ }^{143}$ See, e.g., WiS. StAT. AnN. $§ 70.32(1 \mathrm{~g})$; Md. Code Ann., Tax-Prop. § 9-220; N.H. Rev. Stat. Ann. $\S \S 79-B: 1$ et seq. ${ }^{144}$ N.Y. TAX LAW $\S 606(\mathrm{kk})$.

14535 Ill. COMP. STAT. ANN. 200/10-166.

${ }^{146}$ IDAHO CODE ANN. § 55-2109.

${ }^{147}$ See, e.g., Blackie, Note, Conservation Easements and the Doctrine of Changed Conditions, 40 HASTINGS L.J. 1187 (1989); Covington, Conservation Easements: A Win/Win for Preservationists and Real Estate Owners, 84 ILL. B.J. 628 (1996); O’Connor, Amending Conservation Easements: Legal and Policy Considerations, EXCHANGE, J. OF THE Land Trust Alliance 8 (Spring 1999); Arpad, Note, Private Transactions, Public Benefits, and Perpetual Control Over the Use of Real Property: Interpreting Conservation Easements as Charitable Trusts, 37 REAL PROP. PROB. \& TR. J. 91 (2002); Tapick, Note, Threats to the Continued Existence of Conservation Easements, 27 COLUM. J. ENVTL. L. 257 (2002); Mahoney, Perpetual Restrictions on Land and the Problem of the Future, 88 VA. L. REV. 739 (2002); McLaughlin, Rethinking the Perpetual Nature of Conservation Easements, 29 HARV. ENVTL. L. REV. 421 (2005); Pidot, Reinventing Conservation Easements: A Critical Examination and Ideas for Reform (Lincoln Institute of Land Policy 2005); Greene, Dynamic Conservation Easements: Facing the Problem of Perpetuity in Land Conservation, 28 Seattle U. L. ReV. 883 (2005); McLaughlin, Amending Perpetual Conservation Easements: A Case Study of the Myrtle Grove Controversy, 40 U. RICH. L. REV. 1031 (2006); King \& Fairfax, Public Accountability and Conservation Easements: Learning from the Uniform Conservation Easement Act Debates, 46 NAT. RES. J. 65 (2006); McLaughlin, Conservation Easements: Perpetuity and Beyond, 34 Ecology L. Q. 673 (2007); Korngold, Solving the Contentious Issues of Private Conservation Easements: Promoting Flexibility for the Future and Engaging the Public Land Use Process, 2007 UtAH L. ReV. 1039; McLaughlin \& Machlis, Protecting the Public Interest and Investment in Conservation: A Response to Professor Korngold's Critique of Conservation Easements, 2008 UTAH L. REV. 1561; Research Report, Amending Conservation Easements: Evolving Practices and Legal Principles (Land Trust Alliance
} 
Report does not attempt to address the various positions on these issues. Instead, this Report briefly summarizes (i) the relevant UCEA provisions and comments, (ii) relevant state enabling statute provisions, (iii) the relevant federal charitable income tax deduction requirements and related case law, as well as concerns expressed by the IRS and Senate Finance Committee regarding conservation easement amendment and extinguishment, and (iv) the position of the RESTATEMENT (THIRD) OF PROPERTY: SERVITUDES.

\section{(i) The UCEA}

Section 2(a) of the UCEA provides that, "except as otherwise provided in this Act, a conservation easement may be created, conveyed, recorded, assigned, released, modified, terminated, or otherwise altered or affected in the same manner as other easements." The UCEA drafters explained that, "except to the extent otherwise indicated in the Act, conservation easements are indistinguishable from easements recognized under the pre-Act law of the state.... [and $\S 2(a)$ ] reflects the Act's overall philosophy of bringing less-than-fee conservation interests under the formal easement rubric and of extending that rubric to the extent necessary to effectuate the Act's purposes given the adopting state's existing common law and statutory framework."148

2007); Lindstrom, Hicks v. Dowd: The End of Perpetuity?, 8 WYO. L. REV. 25 (2008); McLaughlin \& Weeks, In Defense of Conservation Easements: A Response to The End of Perpetuity, 9 WYO. L. REV. 1, 87-91 (2009); Lindstrom, Conservation Easements, Common Sense and the Charitable Trust Doctrine, 9 WYO. L. REV. 397 (2009); McLaughlin \& Weeks, Hicks v. Dowd: Conservation Easements and the Charitable Trust Doctrine: Setting the Record Straight, 10 WyO. L. REV. 1 (2010); Richardson, Note, Conservation Easements as Charitable Trusts in Kansas: Striking the Appropriate Balance Among the Grantor's Intent, the Public's Interest, and the Need for Flexibility, 49 Washburn L.J. 175 (2009); Bray, Reconciling Development and Natural Beauty: The Promise and Dilemma of Conservation Easements, 34 HARV. ENVTL. L. REV. 119 (2010); Doscher et al., Amending or Terminating Conservation Easements: Conforming to State Charitable Trust Requirements, Attorney General Guidelines for New Hampshire Easement Holders (2010); Pidot, Conservation Easement Reform: As Maine Goes Should the Nation Follow?, 74 Duke J.L. \& ConTEMP. ProBs. 1 (2011); Owley, Changing Property in a Changing World: A Call for the End of Perpetual Conservation Easements, 30 STAN. ENVTL L.J. 121 (2011); Jay, When Perpetual is Not Forever, The Challenge of Changing Conditions, Amendment, and Termination of Perpetual Conservation Easements, 36 Harv. Envtl. L. Rev. 1 (2012); Schwing, Perpetuity is Forever, Almost Always: Why it is Wrong to Promote the Amendment and Termination of Perpetual Conservation Easements, 37 HARV. ENVTL. L. REV. 217 (2013); Colinvaux, Conservation Easements: Design Flaws, Enforcement Challenges, and Reform, 3 UTAH L. REV. 755 (2013); Burnett, The Uniform Conservation Easement Act: Reflections of a Member of the Drafting Committee, 2013 UTAH L. REV. 773; Wolf, Conservation Easements and the "Term Creep" Problem, 2013 UTAH L. REV. 787; McLaughlin \& Pidot, Conservation Easement Enabling Statutes, Perspectives on Reform, 2013 UTAH L. REV. 811; Leslie, Conservation Easements as Charitable Property: Fiduciary Duties and the Limits of Charitable Self-Regulation, 2013 UTAH L. REV. 849; Knowles, Amending or Terminating Conservation Easements: The New Hampshire Experience, 2013 UTAH L. REV. 871; Phelps, Preserving Perpetuity?: Exploring the Challenges of Perpetual Preservation in an Everchanging World, 43 ENVTL. L. 941 (2013); Levin, A Guided Tour of the Conservation Easement Enabling Statutes 14 (Land Trust Alliance 2014); Hamilton, Understanding the Debate About Conservation Easement Amendments, SAVING LAnd, J. of the Land Trust Alliance (Winter 2014); Domzai, Comment, Preserving Preservation: Long Green Valley Association, Conservation Easements, and Charitable Trust Doctrine, 73 Md. L. Rev. 986 (2014); Korngold, Munteanu, Smith, An Empirical Study of Modification and Termination of Conservation Easements: What the Data Suggest About Appropriate Legal Rules, 24 N.Y.U. EnVTL. L.J. 1 (2016); Downing, Terminating and Amending Conservation Easements in Colorado, 45-AUG CoLO. LAW. 47 (2016).

${ }^{148}$ UCEA, supra note $1, \S 2 \mathrm{cmt}$. For a discussion of the UCEA drafters' intent with regard to this provision, see Burnett, The Uniform Conservation Easement Act: Reflections of a Member of the Drafting Committee, 2013 UTAH L. REV. 773. 
Section 2(c) of the UCEA provides that, "except as provided in Section 3(b), a conservation easement is unlimited in duration unless the instrument creating it otherwise provides." Section 3(b) provides that the UCEA "does not affect the power of a court to modify or terminate a conservation easement in accordance with the principles of law and equity." Thus, as noted in Part II.A above, the default rule under the UCEA is an easement of unlimited duration (i.e., a perpetual easement), subject to the power of a court to modify or terminate the easement in accordance with the principles of law and equity.

The UCEA drafters explained that the latitude given the parties to create easements of unlimited duration is consistent with the philosophical premise of the UCEA, and that there are safeguards, including that conservation easements can be created only for certain public-serving purposes and they must be held by government bodies or charitable entities. ${ }^{149}$ The drafters noted that these limitations find their place comfortably within the limitations applicable to charitable trusts, which may be created to last in perpetuity, subject to the power of a court to modify or terminate the trust pursuant to the doctrine of cy pres. ${ }^{150}$ The drafters also noted that the UCEA "leaves intact" an adopting state's existing case and statute law as it relates to the modification and termination of easements and the enforcement of charitable trusts. ${ }^{151}$

The UCEA drafters further explained that allowing the parties to create easements of unlimited duration also enables them to fit within federal tax law requirements, which require that easements be "in perpetuity" if tax benefits are to be derived. ${ }^{152}$ An express goal of the UCEA drafters was to enable parties to structure easement conveyances so as to be eligible for federal tax benefits. ${ }^{153}$

Although an easement of unlimited or perpetual duration is the default rule under the UCEA, the easement grantor and grantee can provide for a different duration in the instrument creating the easement. Thus, the parties are free to draft "term" easements, which automatically expire after a specified term (such as 20 or 30 years). The parties are also free to draft easements that terminate upon the satisfaction of one or more stated conditions, such as mutual agreement of the parties, approval of a public official, or a finding that "profitable farming is no longer feasible" on the property. These latter categories of easements are not intended to protect the conservation or historic values of the land they encumber in perpetuity. Rather, they are intended to protect those values only for the designated term or until the conditions specified for termination are met. Thus, the UCEA authorizes the creation of conservation easements with a variety of durations, and in a wide variety of contexts, including in purchase, charitable gift, bargain-sale, exaction, and mitigation contexts. That said, many conservation easements are drafted to be perpetual, in part

\footnotetext{
${ }^{149} \mathrm{Id}$.

${ }^{150} \mathrm{Id}$

${ }^{151} I d$., $\S 3 \mathrm{cmt}$. Some jurisdictions historically referred to charitable gifts conveyed to charitable corporations for specific purposes (restricted charitable gifts) as "charitable trusts." With the adoption in more than thirty states of the Uniform Trust Code, which applies only to express trusts, restricted charitable gifts are generally no longer referred to as trusts. However, many of the same rules that apply to gifts made in the form of charitable trusts, including the doctrines of deviation and cy pres, also apply to restricted charitable gifts. Accordingly, UCEA references to charitable trusts, which are based on terminology used in 1981, should be read to encompass restricted charitable gifts.

${ }^{152} \mathrm{Id}$., $\S 2 \mathrm{cmt}$.

${ }^{153}$ Id., Prefatory Note 3 ("[ $\left.\mathrm{t}\right]$ he Act enables the structuring of transactions so as to achieve tax benefits which may be available under the Internal Revenue Code").
} 
because many landowners wish to ensure the permanent protection of specific lands that are important to them, their families, and their communities, and in part due to the requirements for the federal tax incentives.

\section{(ii) State Enabling Statutes}

Most of the enabling statues, like the UCEA, enable the parties to create easements of varied durations, with the default being perpetual easements. California, Florida, and Hawaii require that easements be perpetual, as does Ohio with regard to agricultural easements purchased with certain funds. ${ }^{154}$ Massachusetts and Montana require that easements be perpetual or for a term of years. ${ }^{155}$ Pennsylvania, Montana, and West Virginia require that easements have at least a minimum term, as does Virginia with regard to open space easements held by public bodies. ${ }^{156}$ Alabama and Kansas reverse the UCEA's default of unlimited duration and provide that, unless otherwise specified in the instrument of conveyance, the duration of an easement is limited to the lesser of 30 years, the life of the grantor, or the grantor's sale of the property (in Alabama), or the lifetime of the grantor and the easement may be revoked at grantor's request (in Kansas). ${ }^{157} \mathrm{New}$ Mexico provides that the term of an easement is the term stated therein, ${ }^{158}$ and South Dakota provides that the term of an easement must be established by the parties to the easement. ${ }^{159}$ As discussed below, North Dakota stands alone in limiting the duration of any easement created in the state to 99 years, thus precluding the creation of tax-deductible perpetual easements in the state. $^{160}$

Most of the states that adopted the UCEA adopted Section 2(a) (quoted below) without change.

Except as otherwise provided in this Act, a conservation easement may be created, conveyed, recorded, assigned, released, modified, terminated, or otherwise altered or affected in the same manner as other easements.

Mississippi removed "released, modified, terminated, or otherwise altered or affected" from the provision, and added a reference to "the same method and manner."161 Georgia and Oklahoma clarified that conservation easements cannot be created by eminent domain. ${ }^{162}$

\footnotetext{
${ }^{154}$ CAL. CIV. CODE $§ 815.2$ (b) (“A conservation easement shall be perpetual in duration.”); FLA. STAT. ANN. $\S 704.06$ (“Conservation easements are perpetual, undivided interests in property...”); HAW. REV. STAT. ANN. § 198-2(b) (“A conservation easement shall be perpetual in duration."); OHIO REV. CODE ANN. § 5301.691(D)(1) ("The term of an agricultural easement purchased wholly or in part with money from the agricultural easement purchase fund shall be perpetual").

155 MASs. GEN. LAws ANN. ch. 184, § 31; MONT. CODE ANN. §§ 76-6-103(2), 76-6-202.

15632 PA. CONS. STAT. ANN. § 5054(d) (25-year minimum); MonT. CodE ANN. § 76-6-202 (15-year minimum); W. VA. CODE $\S 20-12-4$ (c) (25-year minimum), VA. CODE ANN. $\S 10.1-1701,10.1$-1703(iii) (5-year minimum).

${ }^{157}$ Ala. CODE $\S 35-18-2(\mathrm{c})$; KAN. STAT. ANN. $\S 58-3811(\mathrm{~d})$.

158 N.M. STAT. § 47-12-3.D.

159 S.D. CODIFIED LAWS $§ 1-19 B-57$.

${ }^{160}$ See infra notes 184 to 186 and accompanying text.

161 Miss. CODE ANN. $§ 89-19-5(1)$.

162 GA. CodE AnN. § 44-10-3(a); OKLA. StAT. AnN. tit. 60, § 49.3.A.
} 
Most of the states that adopted the UCEA also adopted Section 3(b) (quoted below) without change.

This Act does not affect the power of a court to modify or terminate a conservation easement in accordance with the principles of law and equity.

Louisiana did not include Section 3(b) in its statute. ${ }^{163}$ Alabama added a specific reference to the doctrine of changed conditions to the Section. ${ }^{164}$ Arizona added that "In determining whether to modify or terminate a conservation easement a court shall consider the public interest to be served." 165 Pennsylvania and West Virginia added that a court shall exercise such power consistent with the public policy of the enabling statute when the easement is broadly construed to effect that policy. ${ }^{166}$ Both Pennsylvania and West Virginia also added a provision requiring that easements be liberally construed in favor of effecting their conservation purposes and the policy and purpose of the enabling statute, as noted in Part VI.E above.

In 2007, Maine made extensive revisions to its enabling statute regarding the amendment and termination of conservation easements. The revised statute requires that all easements include a statement of the holder's power to agree to amendments in a manner consistent with the limitations set forth in the statute. ${ }^{167}$ The statute further provides, in part:

A conservation easement may not be terminated or amended in such a manner as to materially detract from the conservation values intended for protection without the prior approval of the court in an action in which the Attorney General is made a party. In making this determination, the court shall consider, among other relevant factors, the purposes expressed by the parties in the easement and the public interest. If the value of the landowner's estate is increased by reason of the amendment or termination of a conservation easement, that increase must be paid over to the holder or to such nonprofit or governmental entity as the court may designate, to be used for the protection of conservation lands consistent, as nearly as possible, with the stated publicly beneficial conservation purposes of the easement. ${ }^{168}$

Rhode Island (a non-UCEA state) made similar changes to its statute, which provides, in part:

A conservation or preservation restriction may not be terminated or amended in such a manner as to materially detract from the conservation or preservation values intended for protection without the prior approval of the court in an action in which the attorney general

\footnotetext{
${ }^{163}$ LA. REV. STAT. ANN. $§ \S 9: 1271$ to :1276.

${ }^{164}$ ALA. CODE $§ 35-18-3($ b).

165 ARIZ. REV. STAT. ANN. § 33-273.B.

16632 PA. CONS. STAT. ANN. § 5055(c)(1) ("This act shall not affect the power of a court to modify or terminate a conservation or preservation easement in accordance with the principles of law and equity consistent with the public policy of this act as stated under [ $\S 5052]$ when the easement is broadly construed to effect that policy."); W. VA. CODE $\S 20-12-5$ (b) ("This article does not affect the power of a court to modify or terminate a conservation or preservation easement in accordance with the principles of law and equity consistent with the public policy of this article as stated under section two of this article, when the easement is broadly construed to effect that policy.").

${ }^{167}$ Me. ReV. StAT. ANN. tit. 33, § 477-A.2.A.

${ }^{168} I d$., $§ 477-\mathrm{A} .2 . \mathrm{B}$.
} 
has been made a party. Termination may be approved only when it is found by the court that the conservation or preservation restriction does not serve the public interest or publicly beneficial conservation or preservation purpose, taking into account, among other things, the purposes expressed by the parties in the restriction. An amendment that materially detracts from a specific conservation or preservation value intended for protection may be approved only when it is found by the court that the proposed amendment: is between a separate distinct conservation or preservation restriction holder and the fee landowner; creates a net gain in the overall conservation or preservation purpose for which it was intended; and is consistent with the conservation or preservation purposes expressed by the parties in the restriction and the public conservation or preservation interest. No such approval may be sought except with the consent of the holder. If the value of the landowner's estate is increased by reason of the amendment or termination of a conservation or preservation restriction, that increase shall be paid over to the holder, or to such non-profit or governmental entity as the court may designate, to be used for the protection of conservation lands or historic resources consistent, as nearly possible, with the stated publicly beneficial conservation or preservation purposes of the restriction. ${ }^{169}$

Several other non-UCEA enabling statutes also impose conditions on modification or termination of easements. For example, Massachusetts and New Jersey require the holding of a public hearing and approval of a certain public official or officials to release an easement. ${ }^{170}$ The Virginia statute authorizing the creation of open space easements held by public bodies provides that the easements may be "converted or diverted" if, among other things, the public body determines that the conversion or diversion is essential to the orderly development and growth of the locality and in accordance with the official comprehensive plan. ${ }^{171}$ Montana's enabling statute contains a somewhat similar provision. ${ }^{172}$ In New Hampshire, the Attorney General's office, in collaboration with the state's land trust community, issued guidelines for the amendment and termination of conservation easements that are based on the principles governing charitable assets. ${ }^{173}$

\section{(iii) Federal Tax Law Requirements}

\section{(a) Internal Revenue Code $§ 170(h)$}

Pursuant to $\S 170(\mathrm{~h})$, a property owner donating a conservation easement is eligible for a federal charitable income tax deduction provided (i) the easement is granted in perpetuity to a qualified organization (defined as a governmental unit, a publicly-supported charity, or satellite of such charity) exclusively for one or more of four specified conservation purposes, and (ii) the

\footnotetext{
${ }^{169}$ R.I. GEN. LAWS $§ 34-39-5(\mathrm{c})$.

${ }^{170}$ MASS. GEN. LAws ANN. ch. 184, § 32; N.J. STAT. ANN. §§ 13:8B-5, 13:8B-6.

${ }^{171}$ See supra note 96 and accompanying text.

172 See Mont. Code Ann. $§$ 76-6-107. For additional examples of statutes imposing conditions on modification or termination, see, e.g., Nebraska, New York, and North Carolina.

${ }^{173}$ Doscher et al., Amending or Terminating Conservation Easements: Conforming to State Charitable Trust Requirements (2010), available at https://www.doj.nh.gov/charitable-trusts/documents/conservation-easementsguidelines.pdf. See also Knowles, Amending or Terminating Conservation Easements: The New Hampshire Experience, 2013 UTAH L. REV. 871.
} 
conservation purpose of the easement is protected in perpetuity. ${ }^{174}$ The four conservation purposes for which tax-deductible easements can be granted are outdoor recreation or education of the general public, habitat protection, the preservation of open space, and the preservation of historic land areas or structures. ${ }^{175}$ The Treasury Regulations interpreting $\S 170(\mathrm{~h})$, among other things, set forth requirements intended to ensure that tax-deductible easements will be granted in perpetuity and their conservation purposes will be protected in in perpetuity. ${ }^{176}$

In 2014, in Belk v. Commissioner, the Fourth Circuit Court of Appeals upheld the complete disallowance of a deduction under $\S 170(\mathrm{~h})$ for the donation of a conservation easement because the easement permitted the holder to agree to substitutions or "swaps" (i.e., to remove protected land from the easement, which would constitute an extinguishment, in exchange for the addition of a similar amount of adjacent land to the easement). ${ }^{177}$ The Fourth Circuit held that, to be eligible for a federal deduction for the donation of a conservation easement: (i) the easement must be a restriction granted in perpetuity on the use that may be made of a specific, defined parcel, and (ii) the easement must be extinguishable, whether in whole or in part, only in a judicial proceeding upon a finding that continued use of the property for conservation purposes has become impossible or impractical. The Fourth Circuit explained:

The Treasury Regulations offer a single - and exceedingly narrow-exception to the requirement that a conservation easement impose a perpetual use restriction. The regulations provide that in the event that a

subsequent unexpected change in the conditions surrounding the property ... make[s] impossible or impractical the continued use of the property for conservation purposes, the conservation purpose can nonetheless be treated as protected in perpetuity if the restrictions are extinguished by judicial proceeding and all of the donee's proceeds ... from a subsequent sale or exchange of the property are used by the donee organization in a manner consistent with the conservation purposes of the original contribution.

Treas. Reg. § 1.170A-14(g)(6)(i) (emphasis added). Thus, absent these "unexpected" and extraordinary circumstances, real property placed under easement must remain there in perpetuity in order for the donor of the easement to claim a charitable deduction. ${ }^{178}$

In an earlier case, Carpenter v. Commissioner, the Tax Court similarly held:

\footnotetext{
${ }^{174}$ I.R.C. $\S 170(\mathrm{~h})(1),(\mathrm{h})(2)(\mathrm{C}),(\mathrm{h})(3),(\mathrm{h})(5)(\mathrm{A})$.

${ }^{175}$ I.R.C. $\S 170(\mathrm{~h})(4)$.

${ }^{176}$ See Treas. Reg. $\$ 1.170 \mathrm{~A}-14$.

${ }^{177}$ Belk v. Commissioner, 774 F.3d 221 (4 ${ }^{\text {th }}$ Cir. 2014). For similar holdings, see Balsam Mountain v. Commissioner, T.C. Memo. 2015-43 and Bosque Canyon Ranch v. Commissioner, T.C. Memo. 2015-130.

${ }^{178}$ Belk, 774 F.3d at 225. The Fourth Circuit further explained that to hold otherwise would render certain of the requirements critical to the statutory and regulatory scheme governing the deduction, such as the baseline documentation and qualified appraisal requirements, meaningless. The court explained, for example, that It matters not that the Easement requires that the removed property be replaced with property of "equal or greater value," because the purpose of the appraisal requirement is to enable the Commissioner, not the donee or donor, to verify the value of a donation. The Easement's substitution provision places the Belks beyond the reach of the Commissioner in this regard.

Id. at 226 (emphasis in original).
} 
To make our position clear, extinguishment by judicial proceedings is mandatory. Therefore, we reject [the taxpayers'] argument that section 1.170A-14(g)(6), Income Tax Regs., contemplates any alternative to judicial extinguishment. ${ }^{179}$

In Carpenter, the court also held that the conservation easements at issue, while not charitable trusts under Colorado law, were restricted charitable gifts, or "contributions conditioned on the use of the gift in accordance with the donor's precise directions and limitations," quoting Schmidt, Modern Tomb Raiders: Nonprofit Organizations' Impermissible Use of Restricted Funds, 31 Colo. LAW. 57, 58 (2002). ${ }^{180}$

The IRS has issued guidance regarding the rules governing extinguishment of taxdeductible easements. In a March 2012 General Information Letter, the IRS advised that conservation easements that are subject to swaps other than in the very limited situation of a swap that meets the judicial extinguishment, impossibility or impracticality, and division and use of proceeds requirements of Treasury Regulation $\S 1.170 \mathrm{~A}-14(\mathrm{~g})(6)$ are not deductible. ${ }^{181}$ In a September 2012 Information Letter, the IRS advised that, while state law may provide a means for extinguishing a conservation easement for state law purposes, the requirements of $\S 170(\mathrm{~h})$ and the Treasury Regulations, including the judicial extinguishment and division of proceeds regulations, must nevertheless be satisfied for a contribution to be deductible for federal income tax purposes. ${ }^{182}$ The IRS also noted the fundamental maxim of federal tax law that, while state law determines the nature of property rights, it is federal law that determines the federal tax treatment of those rights.

To satisfy federal tax law requirements regarding extinguishment, the parties typically include a provision in the conservation easement instrument stating that the easement is extinguishable, in whole or in part, only in a judicial proceeding, upon a finding of impossibility or impracticality, and with the payment of the required share of proceeds to the holder to be used in a manner consistent with the conservation purposes of the original contribution. ${ }^{183}$

\footnotetext{
${ }^{179}$ Carpenter v. Commissioner, T.C. Memo. 2013-172, denying reconsideration of and supplementing Carpenter v. Commissioner, T.C. Memo. 2012-1.

${ }^{180}$ Carpenter v. Commissioner, T.C. Memo. 2012-1, supplemented by Carpenter v. Commissioner, T.C. Memo. 2013172. See also Adam Looney, Charitable Contributions of Conservation Easements, 24 Tax Notes Doc. 2017-56478 (Brookings Institution, May 2017) (land trusts report conservation easements for financial accounting and IRS Form 990 purposes as having zero or nominal value because the easements cannot be sold or otherwise liquidated and are viewed more as a liability than an asset; this method of accounting is not specific to easement donations but may also occur with other non-cash gifts that effectively have no value or represent a liability to the donee, like certain restricted gifts of artwork or property). Cf. Long Green Valley Ass'n v. Bellvale Farms, Inc., 432 Md. 292 (2013) (purchased agricultural easement that could be terminated after 25 years if "profitable farming is no longer feasible" held not to constitute a charitable trust; the court found that the easement was not created to benefit the public and that neither the state's agricultural easement-purchase program nor the easements purchased through that program had a charitable purpose).

${ }^{181}$ Information Letter from Karin Goldsmith Gross, Senior Technician Reviewer, IRS (March 5, 2012), available at http://www.irs.gov/pub/irs-wd/12-0017.pdf.

${ }^{182}$ Information Letter from Karin Goldsmith Gross, Senior Technician Reviewer, IRS (Sept. 18, 2012), available at http://bit.ly/1VMfimR.

${ }^{183}$ Other provisions must also be included in a conservation easement deed to satisfy federal tax law requirements. For a checklist of such provisions, see, e.g., THE CONSERVATION EASEMENT HANDBOOK 313-14 (2d. ed 2005).
} 
In Wachter v. Commissioner, the Tax Court held that North Dakota law, which limits the duration of easements created after July 1, 1977, to a maximum of 99 years, precludes conservation easement donors in the state from qualifying for a deduction under $\S 170(\mathrm{~h})$ because easements in North Dakota cannot be granted "in perpetuity." 184 The court noted: "We look to State law to determine the nature of property rights, whereas Federal law determines the appropriate tax treatment of those rights." "The court further noted that "[b]oth parties allege that the State law at issue here is unique because [North Dakota] is the only State that has a law that provides for a maximum duration that may not be overcome by agreement." 186

The Fourth Circuit in Belk v. Commissioner also addressed the interaction between federal and state law in this context. The taxpayers in Belk argued that, because North Carolina law permits the parties to an easement to mutually agree to amend the easement, a finding that the easement at issue in Belk (which authorized the parties to agree to swaps) was not eligible for a deduction would render all conservation easements in North Carolina nondeductible. The 4th Circuit rejected that argument as unpersuasive, explaining

whether state property and contract law permits a substitution in an easement is irrelevant to the question of whether federal tax law permits a charitable deduction for the donation of such an easement. Contrary to the Belks' suggestion, accepting this fact does not require a conclusion that "no conservation easement could qualify for a deduction unless the applicable state law prohibited amendments to make a substitution of property."... Rather, $\S 170(\mathrm{~h})(2)(\mathrm{C})$ requires that the gift of a conservation easement on a specific parcel of land be granted in perpetuity to qualify for a federal charitable deduction, notwithstanding the fact that state law may permit an easement to govern for some shorter period of time. Thus, an easement that, like the one at hand, grants a restriction for less than a perpetual term, may be a valid conveyance under state law, but is still ineligible for a charitable deduction under federal law. ${ }^{187}$

Easement grantors in all states except North Dakota presumably can draft easements to satisfy the federal tax law perpetuity requirements, and extinguishment of such easements would require satisfaction of both the federal requirements and any applicable state law requirements. For example, the Association of New Jersey Environmental Commissions provides the following information on its website:

\footnotetext{
${ }^{184}$ See Wachter v. Commissioner, 142 T.C. 140 (2014). North Dakota has an enabling statute that authorizes the creation of historic easements to protect historic sites or historic structures. See N.D. CENT. CODE § 55-10-08. However, the duration of any easement in North Dakota is limited to 99 years, with further limitations placed on the duration of waterfowl production area easements and wetlands reserve program easements. See N.D. CENT. CODE $\S$ 47-05-02.1(2) ("Real property easements, servitudes, or any nonappurtenant restrictions on the use of real property...shall be subject to the requirements of this section. These requirements are deemed a part of any agreement for such interests in real property whether or not printed in a document of agreement...The duration of the easement, servitude, or nonappurtenant restriction on the use of real property must be specifically set out, and in no case may the duration of any interest in real property regulated by this section exceed ninety-nine years."). For the history behind North Dakota's hostility to perpetual easements, see, e.g., Krasser, Eight Circuit Declares New Law for Owners of Land Encumbered by FWS Easements, 4 Mo. ENVTL. L. \& POL’Y REV. 158 (1996).

${ }^{185}$ Wachter v. Commissioner, 142 T.C. 140 (2014).

${ }^{186}$ Id.

${ }^{187}$ Belk v. Commissioner, 774 F.3d 221, 228 ( $4^{\text {th }}$ Cir. 2014) (emphasis in original).
} 
Under Section 170(h) of the Internal Revenue Code, a conservation easement must state that it cannot be terminated except through a judicial proceeding, and then only if the court determines it is impossible to accomplish the conservation purposes of the easement....

Bear in mind that the New Jersey [general enabling statute] imposes additional newspaper notice, public hearing and [Department of Environmental Protection] approval requirements as a precondition to the "release" of all or any portion of a conservation restriction.... ${ }^{188}$

In Bjork v. Draper ${ }^{189}$ a land trust took the position that the Illinois enabling statute, which provides that a conservation easement "may be released by the holder of such rights to the holder of the fee," authorized the land trust to agree to "amend" a tax-deductible conservation easement to, among other things, remove land from the protection of the easement (a partial extinguishment) in exchange for the protection of a similar amount of adjacent land. The purpose of removing land from the easement was to permit new owners of the land to construct a driveway turnaround, an action prohibited by the easement. The Illinois Appellate Court invalidated the amendments, explaining that to allow the amendments would render meaningless the provisions in the easement specifying its conservation purpose, prohibiting additional structures and improvements (including driveways), and prohibiting extinguishment of the easement, in whole or in part, without court approval. The terms of the easement were binding on the parties despite the seemingly permissive language in the state enabling statute. ${ }^{190}$

\section{(b) IRS and Senate Finance Committee Concerns}

Guidance under $\S 170(\mathrm{~h})$ was listed in the Treasury's 2016-2017 Priority Guidance Plan. ${ }^{191}$ In October 2016, at the Land Trust Alliance national conference, Karin Gross, Special Counsel in the IRS Office of Chief Counsel in Washington, D.C., announced that the Treasury is working on a proposed rulemaking project regarding conservation easement amendments. She invited attendees to submit suggestions to the IRS regarding the project, including providing examples of amendments that are, and are not, consistent with $\S 170(\mathrm{~h})$ 's "granted in perpetuity," "protected in perpetuity," and "enforceable in perpetuity" requirements.

Ms. Gross stated that the IRS does not view all amendments as bad; rather, the question is what amendments are appropriate and under what circumstances. She indicated that the IRS has the following concerns about amendments:

(i) Section $\S 170(\mathrm{~h})$ requires conservation easements to be granted in perpetuity and enforceable in perpetuity; if the rules governing amendments are too lenient, it could destroy perpetuity.

\footnotetext{
${ }^{188}$ James Wyse, Introduction to Conservation Easements for the Non-Lawyer, Easement Provisions in Brief, 7 (2007), available at http://www.anjec.org/pdfs/EasementCD-EasementProvisionsinBrief.pdf (Association of New Jersey Environmental Commissions) (last visited May 29, 2017).

${ }^{189}$ Bjork v. Draper, 886 N.E.2d 563 (Ill. App. Ct. 2008), appeal denied, 897 N.E.2d 249 (Ill. 2008).

${ }^{190}$ See also infra note 223 and accompanying text (discussing Bjork in the context of standing to sue).

${ }^{191}$ Office of Tax Policy and Internal Revenue Service, 2016-2017 Priority Guidance Plan 14 (updated as of Sept. 30, 2016, released Oct. 31, 2016), available at https://www.irs.gov/pub/irs-utl/2016-2017 pgp 1st quarter update.pdf.
} 
(ii) Amendment authority cannot be so broad that holders and landowners could avoid the judicial extinguishment requirements.

(iii) Landowners must not be permitted to "buy" their way out of restrictions.

(iv) The rules must be structured to minimize abuses.

(v) If only the landowner and holder are involved in the decision making, there would be no checks and balances. See Carpenter v. Commissioner, T.C. Memo 2012-1 (the "restrictions [in a conservation easement] are supposed to be perpetual in the first place, and the decision to terminate them should not be [made] solely by interested parties"").

(vi) If only the landowner and holder are involved in the decision making, landowners, who stand to benefit personally and financially from amendments, could place undue pressure on holders to agree to inappropriate amendments.

(vii) There must be mechanisms in place to ensure, for example, that an amendment does not involve private benefit or private inurement, an amendment does not have a negative impact on the conservation values the easement is intended to protect, an amendment does not permit "inconsistent uses," the baseline documentation report is updated as appropriate, mortgage subordinations are obtained or updated as appropriate, appraisals are obtained as appropriate, and amendments are properly recorded.

(viii) There must be a mechanism to prevent holders from agreeing to undisclosed "discretionary approvals or consents" in lieu of amendments, whereby holders approve new uses on protected lands that may be prohibited or contrary to the purposes of the easement without formally amending the easement so as to avoid the limitations on and reporting obligations associated with amendments.

There are a few cases pending in Tax Court in which the IRS has challenged claimed deductions for easement donations in part on the ground that clauses included in the easement deeds authorizing the parties to agree to amendments violated $\S 170(\mathrm{~h})$ 's perpetuity requirements. It is not certain when the Tax Court will issue decisions in these cases, and the cases may be appealed to the U.S. Courts of Appeals.

Many conservation easements contain a clause authorizing the parties to agree to amendments that are consistent with the conservation purpose of the easement and do not violate $\S 170(\mathrm{~h})$, or language to similar effect. However, determining when an amendment furthers or is consistent with the conservation purpose of an easement, or adversely impacts or changes that purpose, can be difficult. In addition, absent guidance from the IRS or the courts, it is not clear when amendments would violate the perpetuity requirements of $\S 170(\mathrm{~h})$. In 2005, in response to a series of Washington Post articles alleging abuses in the conservation easement donation context, ${ }^{192}$ the Senate Finance Committee held a hearing on the federal tax incentives available

\footnotetext{
${ }^{192}$ See, e.g., Joe Stephens \& David B. Ottaway, Developers Find Payoff in Preservation, WASH. Post, Dec. 21, 2003, at A1; Joe Stephens, For Owners of Upscale Homes, Loophole Pays; Pledging to Retain the Facade Affords a Charitable Deduction, WASH. Post, Dec. 12, 2004, at A1.
} 
with respect to conservation easement donations. In connection with that hearing, the Committee issued a report that, among other things, expressed concerns regarding conservation easement amendments. $^{193}$

The report explains that "[m]odifications to an easement held by a conservation organization may diminish or negate the intended conservation benefits, and violate the present law requirements that a conservation restriction remain in perpetuity." 194 The report notes that modifications made to correct ministerial or administrative errors are permitted under federal tax law. ${ }^{195}$ But the report expresses concern with regard to "trade-off" amendments, which both negatively impact and arguably further the conservation purpose of an easement. ${ }^{196}$ The report provides, as an example, an amendment that would permit the owner of the encumbered land to construct a larger home in exchange for restrictions further limiting the use of the land for agricultural purposes. ${ }^{197}$ The report explains that trade-off amendments may be difficult to measure from a conservation perspective, the weighing of increases and decreases in conservation benefits is difficult to perform by the holder and to assess by the IRS, and the private benefit aspects involve subject inquiries with no bright lines to make determinations. ${ }^{198}$

\section{(iv) Restatement (Third) of Property: Servitudes}

Section 7.11 of the Restatement (Third) of Property: Servitudes (2000) provides the following rules regarding the modification and termination of conservation servitudes:

A conservation servitude held by a governmental body or conservation organization may not be modified or terminated because of changes that have taken place since its creation except as follows:

(1) If the particular purpose for which the servitude was created becomes impracticable, the servitude may be modified to permit its use for other purposes selected in accordance with the cy pres doctrine, except as otherwise provided by the document that created the servitude.

(2) If the servitude can no longer be used to accomplish any conservation purpose, it may be terminated on payment of appropriate damages and restitution. Restitution may include expenditures made to acquire or improve the servitude and the value of tax and other government benefits received on account of the servitude. (3) If the changed conditions are attributable to the holder of the servient estate, appropriate damages may include the amount necessary to replace the servitude, or the increase in value of the servient estate resulting from the modification or termination.

\footnotetext{
193 See Report of Staff Investigation of The Nature Conservancy (Volume I), U.S. Senate Committee on Finance, Executive Summary 10-11 (June 2005), available under "Library," then "Committee Prints" at http://finance.senate.gov/.

${ }^{194}$ Id., Executive Summary 9.

${ }^{195}$ Id., Executive Summary 9, n. 20.

${ }^{196}$ See id. at Part Two, 5.

${ }^{197}$ See id.

${ }^{198}$ Id.
} 
(4) Changes in the value of the servient estate for development purposes are not changed conditions that permit modification or termination of a conservation servitude.

The comments to this section explain, in part:

This section sets forth special rules for modification and termination of conservation servitudes that are enforceable by public bodies or conservation organizations.... Because of the public interests involved, these servitudes are afforded more stringent protection than privately held conservation servitudes, which are subject to modification and termination under $\S 7.10$.

There is a strong public interest in conservation and preservation servitudes. Statutes have been enacted to eliminate questions about their enforceability in all but three states, and their creation is subsidized indirectly by tax deductions and directly through purchases by public agencies and nonprofit corporations. Their importance, underscored by statutory requirements that they be perpetual, will continue to increase as population growth exerts ever-greater pressures on undeveloped land, ecosystems, and wildlife. On the other hand, it is inevitable that, over time, changes will take place that will make it impracticable or impossible for some conservation servitudes to accomplish the purpose they were designed to serve. If no conservation or preservation purpose can be served by continuance of the servitude, the public interest requires that courts have the power to terminate the servitude so that some other productive use may be made of the land.

The rules stated in this section are designed to safeguard the public interest and investment in conservation servitudes to the extent possible, while assuring that the land may be released from the burden of the servitude if it becomes impossible for it to serve a conservation or preservation purpose. This section should be read together with $\S 8.5$ which provides that until a conservation servitude is terminated, it is enforceable by coercive remedies designed to give full effect to the purpose of the servitude. ${ }^{199}$

\section{N. Standing to Sue ${ }^{200}$}

\section{(i) Introduction}

The issue of standing to sue in the conservation easement context is multivalent. Given that a conservation easement involves the owner of the land, the holder of the easement, and the public as beneficiary of the easement, there are a variety of suits that various parties might try to initiate in this context, such as:

\footnotetext{
${ }^{199}$ Restatement (Third) OF Property: Servitudes $\S 7.11 \mathrm{cmt}$. a (2000).

${ }^{200}$ For articles discussing standing in the conservation easement context, see Brown, A Time to Preserve: A Call for Formal Private-Party Rights in Perpetual Conservation Easements, 40 GA. L. REV. 85 (2005); Jay, Third-Party Enforcement of Conservation Easements, 29 VT. L. REV. 757 (2005); Ociepka, Protecting the Public Benefit: Crafting Precedent for Citizen Enforcement of Conservation Easements, 58 ME. L. REV. 225 (2006).
} 
- a suit by the holder or another entity granted a right of enforcement against the landowner for an alleged or threatened violation of the easement;

- a suit by the holder or another entity granted a right of enforcement against a third party for an alleged or threatened trespass or other violation of the easement;

- a suit by the landowner against the holder in which the landowner seeks to quiet title to the parcel, interpret or modify the conservation easement, or terminate the easement in whole or in part;

- a suit by the landowner against the holder where the easement imposes affirmative duties upon the holder and the holder has allegedly breached those duties;

- a suit by the state attorney general on behalf of the public against the holder for allegedly failing to enforce the easement; improperly modifying, releasing, extinguishing, or otherwise altering the easement; or otherwise breaching its fiduciary duties;

- a suit by the state attorney general on behalf of the public against the landowner or a third party for an alleged or threatened violation of the easement;

- a suit by a neighbor, a nonprofit, or other member of the public against the holder for allegedly breaching its fiduciary duties; or

- a suit by a neighbor, a nonprofit, or other member of the public against the landowner for an alleged or threatened violation of the easement.

Each of the parties noted above (the holder, another entity granted a right of enforcement, the landowner, the state attorney general, or a neighbor, nonprofit, or other member of the public) might also seek to intervene in a suit involving a conservation easement.

\section{(ii) The UCEA}

Section 3(a) of the UCEA appears to address most of the standing issues noted in the previous subsection, although in some cases it does so indirectly and by reference to an adopting state's other law. Section 3(a) provides that "[a]n action affecting a conservation easement" may be brought by:

(i) the owner of the subject property,

(ii) the holder of the easement,

(iii) a person having a third-party right of enforcement, ${ }^{201}$ or

(iv) a person authorized by other law.

With regard to the last category, the comments to Section 3 explain that the act recognizes that a state's other applicable law may create standing in other persons: "For example, independently of the Act, the Attorney General could have standing in his capacity as supervisor of charitable trusts, either by statute or at common law." This is consistent with the drafters' intent to leave intact the existing case and statute law of adopting states as it relates to the enforcement of charitable gifts and charitable trusts. ${ }^{202}$ Whether a state attorney general could file suit directly against a landowner or a third party for an alleged or threatened violation of an easement, or would

\footnotetext{
201 "Third-party right of enforcement" means an enforcement right provided in an easement to a government or charitable entity that is eligible to be, but is not a holder. UCEA, supra note $1, \S 1(3)$.

${ }^{202}$ See supra note 151 and accompanying text.
} 
have to file suit against the holder for failing to properly enforce the easement, may depend on state law. ${ }^{203}$ However, "[i]n the United States, almost every state attorney general has the authority to regulate charities, either under common law or state statute." 204

Depending on the circumstances and state law, "a person authorized by other law" might also include a neighbor, a nonprofit, or other member of the public, although most cases to date have denied members of the public standing to sue in the easement context.

\section{(iii) State Enabling Statutes}

The state enabling statutes reflect a variety of approaches to the standing issue.

Some of the non-UCEA statutes are silent on the issue. ${ }^{205}$ Others contain provisions that address the enforcement of easements and reference certain parties as having enforcement rights (e.g., the owner of the land, the holder of the easement, or a third party granted a right of enforcement). ${ }^{206}$ The state attorney general's supervisory role with regard to charities and charitable assets, and the potential right of others to sue a holder for a breach of its fiduciary duties, are not addressed in these statutes and such issues presumably are left to the states' other law.

Many of the states that adopted the UCEA adopted the UCEA's four-pronged standing provision. ${ }^{207}$ Four of the states that adopted the UCEA excluded "a person authorized by other law" from the standing provision. ${ }^{208}$ The legislatures in these four states may have been concerned that such language might be interpreted to grant neighbors or others members of the public standing to sue the holder and landowner for an alleged or threatened violation of an easement, or grant the attorney general the right to file suit directly against a landowner for an alleged or threatened violation of an easement. Alternatively, the legislatures may have deemed the language superfluous, since a state's "other law" might apply regardless of the presence of language acknowledging its application.

Mississippi and Virginia modified the UCEA standing provision to expressly grant the attorney general and certain state agencies standing.

Mississippi: "Any action to enforce a conservation easement may be brought by:

(a) An owner of an interest in the real property burdened by the easement;

\footnotetext{
${ }^{203}$ See, e.g., Lefkowitz v. Lebensfeld, 415 N.E.2d 919 (N.Y. 1980) (attorney general did not have authority to bring direct suit against third parties on behalf of charities); Bothelo v. Griffin, 25 P.3d 689 (Alaska 2001) (attorney general had authority to bring direct suit against professional fundraisers on behalf of charities).


March 20, 2017). See also the Uniform Law Commission's Model Protection of Charitable Assets Act (2011), which states and clarifies the role of the attorney general in the protection of charitable assets.

${ }^{205}$ See, e.g., IOWA CODE ANN. §§ 457A.1 to .8; MD. CODE ANN., REAL PROP. § 2-118.

${ }^{206}$ See, e.g., CAL. CIV. CODE $§ 815.7$ (b) and (c); N.C. GEN. STAT. § 121-39(a); N.Y. ENVTL. CONSERV. § 49-0305.5.

207 See, e.g., ARK. CODE ANN. § 15-20-409(a); DEL. CODE ANN. tit. 7, § 6903(a); D.C. CODE § 42-203(a); FlA. STAT. ANN. § 704.06(9); GA. Code ANN. § 44-10-4(a); Ind. CodE § 32-23-5-6(a); IdAHo Code ANN. § 55-2103(1); KAN. Stat. Ann. § 58-3812(a); Ky. Rev. Stat. AnN. § 382.820(1); Minn. Stat. § 84C.03(a); S.C. CodE AnN. § 27-840(A); OR. REV. STAT. § 271.755(1); TEX. NAT. RES. CODE ANN. § 183.003(a).

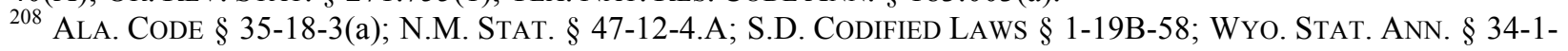
203(a).
} 
(b) A holder of the easement;

(c) A person having a third-party right of enforcement;

(d) The Attorney General of the State of Mississippi;

(e) The Mississippi Department of Wildlife, Fisheries and Parks; or

(f) A person otherwise authorized and empowered by law."209

Virginia: "An action affecting a conservation easement may be brought by:

1. An owner of an interest in real property burdened by the easement;

2. A holder of the easement;

3. A person having an express third-party right of enforcement;

4. The Attorney General of the Commonwealth;

5. The Virginia Outdoors Foundation;

6. The Virginia Historic Landmarks Board;

7. The local government in which the real property is located; or

8. Any other governmental agency or person with standing under other statutes or common law. $" 210$

Arizona modified the UCEA standing provision to add "a government body" in certain circumstances.

An action affecting a conservation easement may be brought by:

1. An owner of an interest in the real property burdened by the easement.

2. A holder of the easement.

3. A governmental body, charitable corporation or trustee of a charitable trust having a third party right of enforcement.

4. A person authorized by other law.

5. A governmental body if the holder is no longer in existence and there is no third party right of enforcement. ${ }^{211}$

The Connecticut and Rhode Island (non-UCEA) enabling statutes expressly grant the state attorney general the right to protect the public interest in conservation easements.

Connecticut: "The Attorney General may bring an action in the Superior Court to enforce the public interest in such restrictions." 212

Rhode Island:

"(d) The attorney general, pursuant to his or her inherent authority, may bring an action in the superior court to enforce the public interest in such restrictions.

\footnotetext{
${ }^{209}$ Miss. CODE ANN. § 89-19-7(1).

${ }^{210}$ VA. CODE ANN. § 10.1-1013.

${ }^{211}$ ARIZ. REV. STAT. ANN. § 33-273.A.

${ }^{212}$ Conn. Gen. StAT. AnN. § 47-42c. Conservation easements are referred to as conservation restrictions in Connecticut.
} 
(f) A court action affecting a conservation restriction held by a private land trust...may only be brought or intervened in by:

(1) An owner of property interest in the real property burdened by the conservation restriction;

(2) A holder of the conservation restriction;

(3) A person having a third-party right of enforcement stated in the recorded conservation restriction; or

(4) The attorney general as provided in subsection 34-39-3(d).",213

The attorney general in each of Connecticut and Rhode Island has defended conservation easements on behalf of the public. ${ }^{214}$

Tennessee and Maine adopted the UCEA standing provision but placed certain limits on the attorney general's right to bring an action affecting a conservation easement. These limits might compromise the attorney general's ability to protect the public interest and investment in conservation easements as noted below.

Tennessee's enabling statute provides:

An action affecting any conservation easement granted on or after July 1, 2005, may be brought by:

(1) An owner of an interest in the real property burdened by the easement;

(2) A holder of the easement;

(3) A person having third-party right of enforcement;

(4) The attorney general and reporter, if the holder is no longer in existence and there is no third-party right of enforcement; or

(5) A person authorized by other law. ${ }^{215}$

Conservation easements granted in Tennessee before July 1, 2005, may be enforced by "the holders or beneficiaries of the easement, or their bona fide representatives, heirs, or assigns." 216 The Tennessee enabling statute was revised in 2005 to add the provision above in response to a case in which two nonprofit organizations and a private citizen sued the owner of land encumbered by an easement (a development corporation) and the holder of the easement (a city) for violating the easement. ${ }^{217}$ Land trusts in Tennessee may have requested the revisions due

\footnotetext{
213 R.I. GEN. LAWS § 34-39-3.

${ }^{214}$ See, e.g., Lyme Land Conservation Trust v. Platner,_A.3d_, 2017 WL 2123636 (Conn. 2017) (owner of easementencumbered land violated the easement and injunction and damages were warranted; the Connecticut Attorney General intervened in support of the land trust's enforcement action); Rhode Island Attorney General Advisory Opinion to Thomas E. Hefner, Town Solicitor, Town of Cumberland, dated June 5, 2015 (Rhode Island Attorney General advised a town council that it did not have the legal right to unilaterally terminate a conservation easement imposed by a previous town council; "a conservation easement expressly may not be terminated without prior approval of a court"). Attorneys General in a number of other states have also defended conservation easements on behalf of the public (e.g., in California, New Hampshire, New Jersey, Maryland, Pennsylvania, Virginia, and Wyoming).

215 TENN. CODE ANN. § 66-9-307(a).

${ }^{216}$ Id. $\S 66-9-307(\mathrm{~b})$.

${ }^{217}$ For a discussion of the case, which settled, see McLaughlin, Conservation Easements: Perpetuity and Beyond, 34 ECOLOGY L. Q. 673, 695-700 (2007).
} 
to a concern that any member of the public as a "beneficiary" would have standing to sue regarding the interpretation and enforcement of easements.

The revised Tennessee statute appears to preclude the Tennessee Attorney General from filing suit directly against a landowner or third party who is violating or threatening to violate a conservation easement if the holder of the easement is still in existence or there is a third-party right of enforcement. Whether the statute precludes the Attorney General from filing a suit against the holder of an easement for a breach of its fiduciary duties with regard to an easement is unclear, although presumably the state legislature did not intend to prevent the Attorney General from protecting the public interest and investment in easements in such cases.

Maine's enabling statute provides:

$\S 478.1$. Action or intervention. An action affecting a conservation easement may be brought or intervened in by:

A. An owner of an interest in the real property burdened by the easement;

B. A holder of the easement;

C. A person having a 3rd-party right of enforcement; or

D. The Attorney General; except that the Attorney General may initiate action seeking enforcement of a conservation easement only when the parties designated as having the right to do so under the terms of the conservation easement:

(1) Are no longer in legal existence;

(2) Are bankrupt or insolvent;

(3) Cannot be contacted after reasonable diligence to do so; or

(4) After 90 days' prior written notice by the Attorney General of

the nature of the asserted failure, have failed to take reasonable actions to bring about compliance with the conservation easement.

2. Intervention only. An action affecting a conservation easement may be intervened in by a political subdivision of the State in which the real property burdened by the easement is located, in accordance with court rules for permissive intervention. $^{218}$

The ninety-day waiting period was presumably included in the Maine statute to signal that the holder of an easement and any third party granted a right of enforcement have the primary obligation to enforce the easement, and the Attorney General serves only as a back-up enforcer. The ninety-day waiting period could be troublesome in some contexts, however, as it may prevent the Attorney General from acting quickly when necessary to prevent irreparable harm, such as the cutting of timber or the razing of an historic building.

The Maine Supreme Court recently interpreted the provision in Maine's enabling statute (which is based on the UCEA) that grants "[a]n owner of an interest in the real property burdened

\footnotetext{
${ }^{218}$ Me. Rev. StAT. ANN. tit. 33, § 478. For a discussion of Maine's standing provision and a critique of the limits placed on attorney general standing, see McLaughlin \& Pidot, Conservation Easement Enabling Statutes: Perspectives on Reform, 2013 UtAH L. REV. 811, 821-25.
} 
by the easement" the right to bring an action affecting the easement. ${ }^{219}$ Estate of Robbins $v$. Chebeague \& Cumberland Land Trust involved a single conservation easement encumbering 100 acres where each of three parties owned a separate portion of the 100 acres (the easement donor's estate, a town, and a real estate developer). The estate sued the land trust holding the easement and the town, alleging that certain activities to be conducted on the town's portion of the land would violate the easement.

The Maine Attorney General filed an amicus brief in the case. ${ }^{220}$ The Attorney General did not take a position on whether the proposed activities would violate the easement. Rather, he focused on the standing issue, and argued that the statute unambiguously granted the estate standing as "an owner of an interest in the real property burdened by the easement." The Attorney General noted "the very real concern that holders may not enforce the easements they hold" for a variety of reasons, ${ }^{221}$ and explained that, while the Office of the Attorney General may bring an action affecting a conservation easement, the Office's ability to do so is subject to resource and other limitations. The Attorney General further explained:

the logical result of concluding that subsection 478(1)(A) encompasses all the owners of an interest in the property described in a particular conservation easement is greater oversight of conservation easement properties, effected by those persons best suited to do so. Owners of property subject to the same easement are better situated than the Attorney General to know what is happening on the ground and take timely action.... The presence of persons subject to the same easement and those persons' interest in seeing the easement enforced will increase the likelihood that fee owners will use protected properties and holders will administer conservation easements consistent with the grantors' intent, rather than in accordance with their respective personal or institutional interests.... The interpretation of subsection 478(1)(A) advanced by the Attorney General and the Estate will facilitate the conveyance of conservation easements by assuring potential grantors that their wishes will be respected in perpetuity.

The Maine Supreme Court held that the estate did not having standing to sue under Maine's enabling statute because the estate did not have a legal interest in the town's portion of the 100 acres. The court explained that the limitations imposed on the Attorney General's standing rights in the statute support the conclusion that the legislature did not intend to authorize actions by "private" attorneys general. The court also noted the interest in protecting holders from "expensive and complicated enforcement lawsuits to be prosecuted by any party who happens to own land that is also subject to the conservation easement." There was a strong dissent in the case.

The Illinois enabling statute expressly grants standing to certain neighbors.

\footnotetext{
${ }^{219}$ Estate of Robbins v. Chebeague \& Cumberland Land Trust, 154 A.3d 1185 (Me. 2017).

${ }^{220}$ Estate of Robbins v. Chebeague \& Cumberland Land Trust, Amicus Brief of the Office of the Attorney General, Law Docket No. Cum-15-256 (on file with author).

${ }^{221}$ The Attorney General cited Pidot, Conservation Easement Reform: As Maine Goes Should the Nation Follow?, 74 Law \& Contemp. Probs. 1, 13 (2011), which explains that land trusts are frequently deterred from enforcing the easements they hold by "enforcement costs, capacity limitations, or the desire to maintain positive landowner relations."
} 
A conservation right created pursuant to this Act may be enforced in an action seeking injunctive relief, specific performance, or damages in the circuit court of the county in which the area, place, building, structure or site is located by any of the following:

(a) the United States or any agency of the federal government, the State of Illinois, or any unit of local government;

(b) any not-for-profit corporation or trust which owns the conservation right;

(c) the owner of any real property abutting or within 500 feet of the real property subject to the conservation right. ${ }^{222}$

Although the Illinois enabling statute has expressly granted standing to abutting or close neighbors for decades, to date there has been only one case in which a neighbor sued the owner of easement-encumbered land and the holder of the easement to enforce the easement pursuant to this provision. ${ }^{223}$ In Bjork $v$. Draper, the stated purpose of the easement was to retain the lawn and landscaped grounds of a historic home "forever predominantly in its scenic and open space condition." In addition, consistent with federal tax law requirements, the easement provided that it could be extinguished, whether in whole or in part, only in a judicial proceeding. Nonetheless, at the request of new owners of the land (the Drapers), the land trust holding the easement agreed to "amend" the easement to (i) remove part of the protected grounds from the easement (a partial extinguishment) in exchange for protecting other adjacent land so that the new owner could construct a prohibited driveway, and (ii) approve plantings that materially interfered with the easement's scenic purpose. While the court held that the easement could be amended, and cited an amendment to add land as acceptable, the court invalidated the amendments that the land trust had agreed to because they were contrary to the terms and conservation purpose of the easement.

\section{O. Holder Immunity from Liability}

Several enabling statutes protect the holder of an easement and, in Alaska in certain circumstances, the owner of the land, from liability for damage or injury suffered on the subject property.

Alaska:

“(a) In addition to the immunity provided by AS 09.65.200, an owner of land, a portion of which is subject to a conservation easement that is 50 feet or less in width, that has been granted to and accepted by the state or a municipality, and that provides public access for recreational purposes on the land subject to the conservation easement is not liable in tort, except for an act or omission that constitutes gross negligence or reckless or intentional misconduct, for damages to a person who uses the easement to enter onto or remain on the land if

(1) the person had no responsibility to compensate the owner for the person's use of the easement or the land; and

\footnotetext{
222765 ILL. COMP. STAT. ANN. 120/4. The statute also provides that property owners who willfully violate easements may be liable for punitive damages, as noted in supra Part VI.F.(iii).

${ }^{223}$ Bjork v. Draper, 886 N.E.2d 563 (2008), appeal denied, 897 N.E.2d 249 (2008).
} 
(2) the damages arise out of the person's use of the easement for recreational purposes on the land.

(b) The immunity under (a) of this section extends to the grantee of the conservation easement providing public access to the land for recreational purposes."224

Georgia: "The ownership or attempted enforcement of rights held by the holder of an easement shall not subject such holder to any liability for any damage or injury that may be suffered by any person on the property or as a result of the condition of such property encumbered by a conservation easement."225

\section{P. Coordination with Permit Processes}

Several of the enabling statutes provide for coordination of the easement with local permitting processes.

\section{Connecticut:}

"(b) No person shall file a permit application...relating to property that is subject to a conservation restriction or a preservation restriction unless the applicant provides proof that the applicant has provided written notice of such application...to the party holding such restriction...not later than sixty days prior to the filing of the permit application.... If the applicant has provided written notice pursuant to this subsection, the holder of the restriction may provide proof to the state or local land use agency or local building official or director of health that granting of the permit application will violate the terms of the restriction and such agency, official or director shall not grant the permit....

(c) If the applicant fails to comply with the provisions of subsection (b) of this section, (1) the party holding the conservation or preservation restriction, other than a state agency that holds such restriction, may, not later than fifteen days after receipt of actual notice of permit approval, file an appeal with the state or local land use agency or local building official or director of health.... The agency, official or director shall reverse the permit approval upon a finding that the requested land use violates the terms of such restriction....,226

District of Columbia: "Whenever a recorded conservation easement has been registered with the Mayor, written consent of the holder of the registered and recorded conservation easement shall be required prior to the recordation of a subdivision by the Office of the Surveyor, and to the issuance of a permit for construction, demolition, alteration, or repair, except solely for interior work.",227

\footnotetext{
${ }^{224}$ ALASKA STAT. $§ 34.17 .055$.

${ }^{225}$ GA. CODE ANN. § 44-10-3(e). Florida has a virtually identical provision. FLA. STAT. ANN. § 704.06(10).

${ }^{226}$ CONN. GEN. STAT. ANN. $§ 47-42 d(b)$ and (c).

${ }^{227}$ D.C. CODE $§$ 42-201.01.
} 
Georgia: "The easement holder shall be a necessary party in any proceeding of or before any governmental agency which may result in a license, permit, or order for any demolition, alteration, or construction on the property.",228

\section{Q. Transfer Notice Provisions}

Two enabling statutes require that certain parties be notified of transfers involving conservation-easement encumbered land.

Vermont: "Any subsequent transfer, mortgage, lease, or other conveyance of the real property or an interest in the real property shall reference the grant of conservation rights and interests in the real property; provided, however, that the failure to include a reference to the grant shall not affect the validity or enforceability of the conservation rights and interests." 229

West Virginia: "In a manner consistent with common law, the granting of a conservation or preservation easement shall not subsequently restrict the right of the fee owner to further grant any other interest in real property to any person or entity when the grant does not materially impair the prior conservation or preservation easement. When a fee holder grants an interest beyond the conservation or preservation easement, he shall notify the holder of any conservation or preservation easement at least forty-five days prior to the execution of any subsequent easement or any other conveyance of an interest in land encompassed by the conservation or preservation easement." ${ }^{, 230}$

Maryland, in the Contracts of Sale section of its Code, sets forth fairly elaborate notice provisions:

(c) A vendor of real property encumbered by one or more conservation easements shall, on or before entering into a contract for the sale of the property, deliver to each purchaser:

(1) The notice described in subsection (d) of this section; and

(2) A copy of all conservation easements encumbering the property.

(d) The notice required under subsection (c)(1) of this section shall be in a form substantially the same as the following:

"This property is encumbered by one or more conservation easements or other restrictions limiting or affecting uses of the property. Maryland law requires that the vendor deliver to the purchaser copies of all conservation easements on or before the day the contract is entered into. The purchaser should review all conservation easements carefully to ascertain the purchaser's rights, responsibilities, and obligations under each conservation

\footnotetext{
${ }^{228}$ GA. CODE ANN. § 44-10-4(b).

${ }^{229}$ VT. STAT. ANN. tit. 10, $\$ 823$.

${ }^{230}$ W. VA. CODE $§ 20-12-8$.
} 
easement, including any requirement that after the sale the purchaser must inform the owner of the conservation easement of the sale of the property."

(e)

(1) A purchaser who receives the notice and copies of the easements required under subsection (c) of this section on or before entering into a contract of sale does not have the right to rescind the contract of sale based on the information received from the vendor.

(2) A purchaser who does not receive the notice and copies of the easements required under subsection (c) of this section on or before entering into a contract of sale, on written notice to the vendor or the vendor's agent:

(i) Has the unconditional right to rescind the contract at any time before, or within 5 days after, receipt of the notice and copies of the easements; and

(ii) Is entitled to the immediate return of any deposits made in accordance with the contract.

(1) Within 30 calendar days after a sale of property encumbered by a conservation easement, the purchaser shall notify the owner of a conservation easement of the sale.

(2) The notification shall include, to the extent reasonably available:

(i) The name and address of the purchaser;

(ii) The name of the vendor;

(iii) The address of the property; and

(iv) The date of the sale. ${ }^{231}$

\section{R. Protection of Water Areas or Water Rights}

A number of enabling statutes specifically provide that water areas or water rights may be encumbered by a conservation easement. Examples include the following.

Colorado: "'Conservation easement in gross'...means a right in the owner of the easement to prohibit or require a limitation upon or an obligation to perform acts on or with respect to a land or water area, airspace above the land or water, or water rights beneficially used upon that land or water area....,232

Illinois: "A conservation right is a right...appropriate to preserving...land or water areas predominantly in their natural, scenic, open or wooded condition, or as suitable habitat for fish, plants, or wildlife...."233

Michigan: "“Conservation easement' means an interest in land that provides limitation on the use of land or a body of water or requires or prohibits certain acts on or with respect to the land or body of water...which interest is appropriate to retaining or maintaining the land

\footnotetext{
${ }^{231}$ Md. CODE ANN., REAL PROP. $§ 10-705(\mathrm{~b})$-(f).

${ }^{232}$ COLO. REV. STAT. $\S 38-30.5-102$.

233765 ILl. COMP. StAT. ANN. 120/1(a).
} 
or body of water, including improvements on the land or body of water, predominantly in its natural, scenic, or open condition, or in an agricultural, farming, open space, or forest use, or similar use or condition.",234

Rhode Island: “A 'conservation restriction' shall mean a right to prohibit or require a limitation upon or an obligation to perform acts on or with respect to or uses of a land or water area....,235

Maryland's statute defines a conservation easement as "[a]ny restriction prohibiting or limiting the use of water or land areas" for any of the purposes listed in the statute. ${ }^{236}$

Maine's statute provides that the "real property" that may be subject to a conservation easement includes "surface waters." 237

South Carolina's statute similarly provides that the "real property" that may be subject to a conservation easement includes "surface waters.",238

\footnotetext{
${ }^{234}$ MiCH. COMP. LAWS ANN. § 324.2140(a).

${ }^{235}$ R.I. GEN. LAWS $§$ 34-39-2(a).

${ }^{236}$ Md. CODE ANN., REAL PROP. § 2-118(a).

${ }^{237}$ Me. ReV. StAT. ANN. tit. 33, § 476.3.

238 S.C. CODE ANN. § 27-8-20(3).
} 